\title{
"Changes in Wage Structure in Mexico Going Beyond the Mean: An Analysis of Differences in Distribution, 1987-2008"
}

Claudia Tello, Raul Ramos and Manuel Artís 


\section{$\underset{B}{\mathbb{P}}|| R|E| A \mid$}

Institut de Recerca en Economia Aplicada Regional i Públic

Research Institute of Applied Economics

WEBSITE: www.ub-irea.com•CONTACT: irea@ub.edu

\section{AQR}

Grup de Recerca Anàlisi Quantitativa Regional

Regional Quantitative Analysis Research Group

WEBSITE: www.ub.edu/aqr/•CONTACT: $\underline{\text { aqr@ub.edu }}$

\section{Universitat de Barcelona}

Av. Diagonal, $690 \bullet 08034$ Barcelona

The Research Institute of Applied Economics (IREA) in Barcelona was founded in 2005, as a research institute in applied economics. Three consolidated research groups make up the institute: AQR, RISK and GiM, and a large number of members are involved in the Institute. IREA focuses on four priority lines of investigation: (i) the quantitative study of regional and urban economic activity and analysis of regional and local economic policies, (ii) study of public economic activity in markets, particularly in the fields of empirical evaluation of privatization, the regulation and competition in the markets of public services using state of industrial economy, (iii) risk analysis in finance and insurance, and (iv) the development of micro and macro econometrics applied for the analysis of economic activity, particularly for quantitative evaluation of public policies.

IREA Working Papers often represent preliminary work and are circulated to encourage discussion. Citation of such a paper should account for its provisional character. For that reason, IREA Working Papers may not be reproduced or distributed without the written consent of the author. A revised version may be available directly from the author.

Any opinions expressed here are those of the author(s) and not those of IREA. Research published in this series may include views on policy, but the institute itself takes no institutional policy positions. 
This paper conducts an empirical analysis of the relationship between wage inequality, employment structure, and returns to education in urban areas of Mexico during the past two decades (1987-2008). Applying Melly's (2005) quantile regression based decomposition, we find that changes in wage inequality have been driven mainly by variations in educational wage premia. Additionally, we find that changes in employment structure, including occupation and firm size, have played a vital role. This evidence seems to suggest that the changes in wage inequality in urban Mexico cannot be interpreted in terms of a skill-biased change, but rather they are the result of an increasing demand for skills during that period..

JEL classification: J31.

Keywords: wage inequality, quantile regressions, decomposition

Claudia Tello. AQR Research Group-IREA. Department of Econometrics. University of Barcelona, Av. Diagonal 690, 08034 Barcelona, Spain. E-mail: ctello@ub.edu

Raul Ramos. AQR Research Group-IREA. Department of Econometrics. University of Barcelona, Av. Diagonal 690, 08034 Barcelona, Spain. E-mail: rramos@,ub.edu

Manuel Artís. AQR Research Group-IREA. Department of Econometrics. University of Barcelona, Av. Diagonal 690, 08034 Barcelona, Spain. E-mail: manuel.artis@ub.edu 


\section{Introduction}

In this paper, we examine the changes in wage structure in urban Mexico across the entire wage distribution over the past two decades (1987-2008). We use quantile regressions to determine whether this wage distribution has been affected uniformly by human capital variables, by demographic traits and by labour characteristics.

The Mexican case has emerged as an interesting outlier in terms of the relationship between changes in wage inequality and schooling premia internationally. For this reason, we also focus our attention on the changes in returns to various characteristics over the two-decade period.

The paper is structured in two parts: first, using the National Survey of Labour and Employment (ENOE) and the National Urban Employment Survey (ENEU), both carried out by the National Institute of Statistics and Geography of Mexico (INEGI), for the period 1987-2008, we identify the forces that have played a role in the variations recorded in schooling returns and in wage inequality. Second, we apply the quantile decomposition methodology developed by Melly (2005), which permits us to decompose the changes in the wage distribution into changes in covariates, coefficients, and residual components. These results are based on the estimation of a standard Mincerian wage equation, in which levels of education, experience, gender, marital status, occupation, activity sector, firm size, economic sector and urban areas are included as covariates. One advantage of the procedure is that it provides the means for separating the between- and within-group components, as in a variance decomposition. This plays an important role in the inequality literature, since Juhn, Murphy and Pierce (1993) conclude that most of the growth in inequality from the 1980 s to the 2000 s was linked to the residual inequality component. In fact, quantile regression analysis reveals whether the effects of many covariates are constant or not across the wage distribution. Our results show that increases in returns to covariates across the entire distribution were the 
driving forces behind the wage changes in the period under review. Furthermore, the decomposition method proposed in Melly (2005) allows us to evaluate the role of changing labour force composition (in terms of workers' characteristics) and changing labour market in overall changes in the wage distribution between 1987 and 2008. We do not seek to establish causality between the structural changes that occurred during this period and the evolution in wage inequality, but this analysis should help us to identify the direction of change throughout the two decades across the entire wage distribution. For instance, our results show that changes in the composition of the work force in urban Mexico contributed positively to wage growth between 1987 and 1994, but negatively between 1995 and 2000 .

As we outline below, a series of major changes occurred during the period under analysis. Specifically, the Mexican economy underwent numerous reforms — domestic financial market reforms, capital account liberalization, tax reforms, privatization of state-owned enterprises and labour reforms (Lustig, 1998, 2001). Two key events that attract considerable coverage in the literature are the signing of the GATT (General Agreement on Tariffs and Trade) in 1986 and the NAFTA (North American Free Trade Agreement) in 1994. In the mid 1980s, Mexico initiated a major opening up process in which it adopted an aggressive policy of trade liberalization and additional privatization and deregulation reforms. This process was particularly intense in 1987 and 1988. Mexico then entered a period of stabilization (Hanson et al., 1999) and its corporate tax policy was reformed in order to lower distortions in investment. Most studies analysing the second half of the 1990s identify the importance of the devaluation of the peso in December 1994 and the 1995 crisis, the most severe economic crisis that Mexico has witnessed since the 1930s. Yet, later that year, the recovery, which was to be consolidated in 1996 and 1997, was already under way. Mexico's government implemented various anti-poverty policies. However, in 1998, Mexico was hit by several external shocks that pushed the economy ${ }^{1}$ into lower than expected growth and higher than expected inflation. Capital inflows were reduced and the price of oil dropped sharply on international

\footnotetext{
${ }^{1}$ In this year, the Mexican authorities implemented the necessary fiscal and monetary policies to contain the adverse effects of these shocks.
} 
markets. This situation negatively affected Mexico's public finances and the budget deficit target, announced at the beginning of the year, was $1.25 \%$ of GDP. Moreover, the portfolio investments received by Mexico in 1998 were down in relation to the values recorded in the previous two years. The eventual outcome was that in the period 1987 to 2008 , income and wage inequality followed an inverted U-shape pattern (López-Calva and Lustig, 2010; Esquivel, Lustig and Scott, 2010).

The general picture painted by these studies can be summarised as follows: the period from 1987 to 1994 was marked by structural reforms and trade and financial liberalization in the economy, which increased relative demand for skilled labour and also increased inequality. Subsequently, the period between 1994 and 2001 was one of growth and relative stability, with an increased supply of skilled workers and a fall in inequality. Moreover, in this period the levels of education showed a marked increase. Between 2001 and 2008, other reforms were introduced. These reforms entailed changes in the labour force composition, in terms of its education and experience (López-Acevedo, 2006), in terms of supply and demand of labour (Campos-Vazquez, 2010), the effects of trade (Robertson, 2007), the expansion of government monetary transfers targeting the poor, the rise in the share of remittances and the fall in the skill premium between skilled and unskilled workers. Moreover, in the late 1990s, urban informal labour represented a major part of the workforce, with various studies reporting levels oscillating between 20 and $40 \%$. At a later date, the OECD (2007) reported levels of $62 \%$ when taking both agricultural and non-agricultural employment into account. At the end of the period, from 2005 to 2009, Mexico recorded small rates of growth in its real $\mathrm{GDP}^{2}$ while the recession in the United States has been felt directly throughout the country.

To explain changes in wage structure, the standard economic theory focuses on average wage dynamics rather than on changes across the entire wage distribution, thus ignoring any differences at the bottom or the top of the wage distribution. In the case of Mexico, changes in wage structure display interesting

\footnotetext{
${ }^{2}$ Between 2006 and 2008 the rate fell from 4.7 to 2.0 (United Nations, 2009).
} 
patterns in terms of wage levels at different parts of the wage distribution between 1987 and $2008 .^{3}$ Additionally, average wage statistics might conceal significant features in the wage structure. It is important to look beyond the average values so as to obtain a complete picture for three reasons: First, because recent studies in other countries using quantile regression techniques have shown that different characteristics have different effects on individuals' wages at the top of the wage distribution from those recorded at the bottom of the wage distribution; ${ }^{4}$ second, because Mexico is a heterogeneous society and, for this reason, the effects of reforms may well be heterogeneous also; and, third, because there is growing evidence from other countries (e.g., the US) that suggests that, far from being ubiquitous, the growth in wage inequality is increasingly concentrated at the top end of the wage distribution (Lemieux, 2008).

Based on the preceding discussion, this paper contributes to the existing literature in the following ways: First, it estimates earning functions across the entire wage distribution using quantile regression and quantifies the contribution over time of changes in the individual covariates' of workers living in the urban areas of Mexico; second, it decomposes the changes in wages over the past two decades into parts that are attributable to changes in prices (coefficient effect), the changes in characteristics (covariate effect) and the residual components across the entire wage distribution. Melly's (2005) decomposition is well-suited to depict heterogeneous characteristics, coefficients such as between effects and residuals within effects across the entire wage distribution. The idea is to perform simulations between periods and an aggregate decomposition analysis using a conditional procedure. The effects for different quantiles show that the differences in characteristics are much more important at the bottom $\left(10^{\text {th }}\right.$ percentile $)$ than at the top $\left(90^{\text {th }}\right.$ percentile) of the wage distribution. Indeed, some significant wage structure effects emerge at

\footnotetext{
${ }^{3}$ For additional details about the ratio of real hourly wages, see Tello, 2011. For evidence for other periods, see Robertson, 2000; Lustig, 2001; López-Acevedo, 2006 and Campos-Vazquez, 2008.

${ }^{4}$ Evidence for this has been reported from a number of different countries including the USA (Buchinsky, 1994), Germany (Fitzenberger and Kurz, 2003), Uruguay (González and Miles, 2001), Zambia (Nielsen and Rosholm, 2001), Chile (Beyer, Rojas, and Vergara, 1999), Morocco (Currie and Harrison, 1997), and Costa Rica (Robbins and Gindling, 1999), India (Kijima, 2006, who decomposes the changes in the 90th-10th, 90th-50th, and 50th-10th percentiles of the log wage differential) and Portugal (Machado and Mata, 2001).
} 
the $90^{\text {th }}$ percentile. Third, we extend the period of analysis of the previous literature through 2008 by incorporating new data.

The rest of the paper is structured as follows. Section 2 reviews the previous literature. Section 3 introduces the empirical strategy and the data used for our analysis. Section 4 examines, first, the results for wage inequality over time using quantile regression technique and, second, the results of the decomposition results. Section 5 concludes.

\section{Literature review}

An examination of the relationship between education and inequality provides evidence that the rising educational wage differential in Mexico has been an essential element of rising wage inequalities. The research undertaken to date that has sought to capture the patterns of change in wage inequalities has taken a variety of directions focusing on education acquisition and inequality, on the labour market returns to education and on the contributions of increased education demand and supply. ${ }^{5}$ Under certain circumstances, education can serve to strengthen existing inequalities, resulting in increased inequality; under others, education can provide a route out of disadvantage by enabling people from poorer backgrounds to escape poverty. ${ }^{6}$ In the 1990 s, Mexico experienced educational achievements and their distribution across the labour force changed substantially. At the same time, the gap between the wages of the more highly educated and those with little education closed systematically while changes in the returns to education accounted for a significant share of the rise in household per capita income inequality. In contrast, in the next decade, the decline in labour earnings inequality appears to be more closely associated with less steep returns to education functions (which reduced earnings per worker inequality) and much less so - or not at all - to changes in employment patterns. However, an examination of the

\footnotetext{
${ }_{6}^{5}$ See Cragg and Epelbaum, 1996; Meza, 1999; Cortés, 2001; Airola and Juhn, 2005; Boullion et al., 2004.

${ }^{6}$ See López-Calva and Lustig, 2009 and Esquivel et al., 2010.
} 
changes in the composition of the labour force by education and experience and the corresponding relative wages suggests that supply-side factors must have been as important as those on the demand-side (Duryea and Székely, 1998; Legovini et al., 2005; López-Acevedo, 2006; Campos-Vazquez, 2008; Esquivel, 2009; Esquivel et al., 2010). Other studies have measured the impact of educational endowments on earnings inequality in Mexico (see, for example, Legovini et al., 2005; López-Acevedo, 2006; De Hoyos, 2007; Campos-Vazquez, 2008; and Esquivel et al., 2010). However, in order to understand the relationship between human capital accumulation and changes in the wage structures, we believe it necessary to extend the conventional approach based on the analysis of average wages and their determinants using least square methods. Specifically, the impact of human capital variables on the entire wage distribution first needs to be analysed and not solely for average data; and, second, the changes in the wage distribution need to be decomposed into the effects attributable to the different components.

The most influential analyses of income decomposition using Mincerian equations include the early studies of Oaxaca (1973) and Blinder (1973) and the later work of Juhn, Murphy and Pierce (1993). Fortin et al. (2011) provide an interesting overview of decomposition methods that have been developed since the seminal work of Oaxaca and Blinder in the early 1970s. A further regression-based approach is found in two papers by Bourguignon and co-authors (Bourguignon and Martinez, 1997; Bourguignon, Fournier, and Gurgand, 1998). The essence of their procedure is to run two regressions for a base year 1 and a final year 2 and then to decompose the changes into price, quantity, and residual effects. ${ }^{7}$ Machado and Mata (2005), Melly (2005) and Autor et al. (2005) derive counterfactual wage distributions, using alternative sets of covariates, coefficients, and residuals. In this way, the changes over time in the wage distribution are decomposed into price (coefficients), quantity (covariates), and residual (within) effects. These

\footnotetext{
${ }^{7}$ A different line of research abandons the regression framework entirely and examines between-group and within-group inequality (see, Cowell and Jenkins, 1995). A quite distinct method of decomposition is found in the factor components literature. Fei, Ranis and Kuo (1978) and Pyatt, Chen and Fei (1980) decomposed total inequality into terms attributable to each factor component (e.g., labour income, capital income, land income). The former authors showed that the Gini coefficient of total income can be decomposed into a weighted sum of pseudo-Ginis, the weights being given by the corresponding factor shares.
} 
methods are based on conditional quantiles and adhere to the assumptions that are required to make the economic interpretations. ${ }^{8}$

In line with this latter approach, we investigate the relationship between employment structure and wage inequality in Mexico, and argue that the changes in the wage inequality trend over the past two decades are actually the result of countervailing effects, which are related to changes in covariates (employment structure), coefficients (educational wage premia and other characteristics), and residuals.

The international evidence shows that large shifts in labour force composition have the potential to contribute to the divergent behaviour of upper- and lower-tail inequality. For example, hypotheses such as falling real minimum wages, declining unionization, and monotonically rising demand for skill do not generally predict steadily increasing upper-tail inequality paired with fluctuating lower-tail inequality. This leads to the supposition that earning trajectories may tend to become more dispersed as workers gain experience of the labour market and that changes in the distribution of education or in the experience of the labour force may result in changes in earnings dispersion. Autor et al. (2008) find that changes in labour force composition in the US do not contribute to an explanation for the diverging path of upperand lower-tail inequality in the past two decades. The composition hypothesis, they argue, fails for two reasons: first, they show that the impact of changes in labour force composition on wage dispersion occurs almost entirely below the median of the earnings distribution (i.e., in the lower tail). This in turn implies that the steady growth of upper-tail inequality during the 1980 s and 1990 s is due to changing labour market prices, as opposed to the mechanical effects of composition. In the 1980s, however, increasing lower-tail inequality appears, they claim, to be explained by changing labour market prices, augmented slightly by shifts in composition. In the 1990s, by contrast, changing market prices generated considerable compression in lower-tail inequality, but these price effects were largely offset by compositional shifts

\footnotetext{
${ }^{8}$ The most relevant assumptions are additive linearity and conditional rank preservation. For more details see Fortin, Lemiux and Firpo (2011).
} 
(which would otherwise have caused lower-tail inequality to increase). The source of the asymmetric rise in earnings inequality with a steady rise in upper-tail wage inequality and some evidence of flat or declining lower-tail wage inequality seems to suggest a "polarization" of the labour market with a particularly strong market for workers at the top end of the skill distribution, deterioration in market conditions for workers in the middle, and reasonably steady market conditions for those near the bottom. ${ }^{9}$ Goos and Manning (2007) conclude that the hypothesis of skill-biased technical change (SBTC) is only a partial truth and cannot explain all of the important changes in the labour market. In other words, the SBTC hypothesis seems best able to explain what is happening in the top half of the wage distribution but not in its bottom half. They claim that new technologies are a substitute for human labour in routine tasks, located in the middle of the wage distribution, and that they are a complement to non-routine cognitive and manual tasks, located respectively at the top and at the bottom of the job quality distribution. These interpretations, however, are not easily extended to Mexico, where different degrees of adoption of new technologies and labour market institutions have produced different wage dynamics with respect to those in English-speaking countries (Gottschalk and Smeeding, 1997).

Nowadays, the empirical evidence for the analysis of wage inequalities using quantile regressions and decomposition techniques in Mexico is limited. López-Acevedo (2006) uses the Labour Force Survey from 1988 to 2002. She reviews the relationship between education and inequality and examines the evolution and structure of the rates of returns to education by means of ordinary least squares and quantile regressions without decomposition. López-Acevedo finds that in the early 1990s the trends in the distribution of earnings in Mexico differ from those in the distribution of current income in two ways. First, the gains are not limited to the richest ten per cent, as those in the seven-, eight-, and nine-tenths of the distribution also improved their relative earnings. Second, the distribution of earnings clearly deteriorated in the 1990s until 1996, although the inequality associated with total current income was

\footnotetext{
${ }^{9}$ Goos and Manning (2007) call such a process the "polarization of work," and argue that it may have contributed to a similar hollowing out of the wage distribution in the United Kingdom during 1975 to 2000.
} 
moderately stable in the 1990s, displaying an improvement after 1996. Differences in the behaviour of total current income and labour earnings inequalities from 1994 to 1996, she claims, support the idea that the poor, who rely most heavily on labour as a source of income, are the least able to protect themselves during a recession. She concludes, therefore, that education is the key variable for understanding income and earnings inequality in Mexico and that it is the variable that accounts for the largest share of earnings inequality by far in the country, in terms of both its gross and its marginal contribution. Indeed, the marginal contribution of education to the explanation of inequality in Mexico is almost equal to the joint contribution of other relevant variables that include age, economic sector, labour market status and hours worked. Interestingly, she reports that the difference between the gross and marginal contributions has increased over time, indicating that, as the economy progresses, education has become even more important in determining the choices of sectors and occupations. Campos-Vazquez (2008) reviews the sources of the fall in wage inequality and job polarization in the post-NAFTA period using the Machado and Mata (2005) and Bound and Johnson decompositions (1992) with quantile regressions. ${ }^{10}$ CamposVazquez found that the main reasons why inequality has fallen are driven by supply and demand forces; the slower demand growth and the increase in the supply of college workers was not matched by an increase in top qualified jobs. ${ }^{11}$ The results of the decomposition show that the returns to education and labour experience are the most important factors explaining the decrease in wage inequality. The decline in returns is explained by a substantial increase in college graduates in the last ten years, but it is also due to slower growth in labour demand, especially for the top paid jobs. These results confirm that changes in relative supply are the main determinant behind the decrease in wage inequality. Sámano (2010) analyses income inequality in Mexico using the hierarchical approach (Atkinson, 2008) and the decomposition method proposed by Machado and Mata (2005). She reviews groups of workers with high levels of education and occupations that are related to the new technologies. She reports relevant differences between deciles, in particular for those at the bottom of the distribution.

\footnotetext{
${ }^{10}$ In the empirical application Campos-Vazquez (2008) employed the Expenditure Survey (ENIGH) and he only controled for education, experience, gender and region variables..

${ }^{11}$ Arias et al. (2001) test the returns to education using instrumental variables quantile regression and treatment effects. They concentrate their research on the effects of education on the whole conditional distribution of wages.
} 


\section{Data and methodology}

\subsection{Data}

The data used in this study are drawn from the National Survey of Labour and Employment (ENOE) and the National Urban Employment Survey (ENEU) carried out by the National Institute of Statistics and Geography of Mexico (INEGI). We analyse the wage structure and undertake a decomposition analysis from 1987 to 2008. We include 38 urban areas (localities with at least 2,500 inhabitants), although information was actually collected for 48 areas. However, as these localities changed at various points in this period, we eventually consider just the 38 time-invariant regions to facilitate subsequent comparisons. The sample consists of employees aged 15 to 65 and we focus specifically on those with permanent jobs working full-time (dedication being measured in terms of the number of hours spent working in their principal job). We refer to the logarithm of the real hourly wage, obtained by dividing the monthly wage (earnings from the main job after taxes and social security contributions, including overtime premia and bonuses) and deflating by regional consumer price indexes (base year 2002). For those paid weekly, the survey transforms weekly earnings into a monthly wage. Similar adjustments are made for workers paid daily or every two weeks.

Human capital accumulation is analysed by level of education, comprising five categories: no schooling or primary incomplete; primary complete; secondary; upper secondary and higher or tertiary. Table 1 provides the mean of the log real hourly wage, schooling years, age and potential experience for workers in our sample. We observe that real wages increased throughout the wage distribution between 1987 and 1994 and fell between 1995 and 1996 (coinciding with the peso crisis). In the following years, real wages presented a slight upward trend at different points of the wage distribution. Urban areas in Mexico contain a greater proportion of individuals with a high level of education. Between 1987 and 2008 there was a 
substantial increase in education levels reflecting concerted efforts to increase the coverage of primary and secondary education. ${ }^{12}$ The average number of years of schooling has increased from 8.76 to 10.87 rising by more than two years over the period. As shown in Figures 1 and 2, a clear trend can be observed between 1987 and 2008 in terms of the number of schooling years, but a different picture emerges for real wages. During the same period, the workforce's potential experience increased from 16.38 years in 1987 to 18.31 years in 2008 while the average age of the labour force over the period was 32.62 years.

\section{TABLE 1}

\section{FIGURES 1 and 2}

\subsection{Quantile regression}

In this section we disentangle the contribution of labour force characteristics and labour market prices in the dynamics of the Mexican wage structure. This line in the literature can be traced back to the seminal contributions of Oaxaca and Blinder in 1973, and it has been developed considerably over the last three decades most specifically with the non-parametric decomposition described by DiNardo et al. (1996). The most recent contribution to the literature is the consideration of a quantile regression, which explores the dynamics of the whole wage distribution. Here, we adopt a methodology that has been recently developed by Melly $(2005)^{13}$ in a paper that draws on the same general idea as Machado-Mata (2005) but which employs slightly different techniques in its implementation.

\footnotetext{
12 The Mexican education system provides six years of primary education and three years of secondary education (junior high equivalent). Primary education is free and compulsory. In 1992, the three years of junior high were also made compulsory. And since 2012-2013 academic year the upper secondary (senior high equivalent) will be compulsory.

${ }^{13}$ As stressed by Autor et al. (2005), the Machado-Mata method for calculating counterfactual densities is closely related to the kernel reweighting approach proposed by DiNardo, Fortin and Lemieux (1996) and improved by Lemieux (2002a, 2006). Furthermore, the Machado-Mata approach is readily extended to provide a uniform and consistent treatment of both overall inequality and residual inequality. By contrast, alternative approaches apply a hybridized set of methods (OLS regressions, parametric probability models and kernel reweighting) to derive counterfactuals separately for overall and residual inequality.
} 
This methodology takes as its starting point the quantile estimations from 1987 and 2008, using a standard Mincerian (Mincer, 1958 and 1974) specification:

$$
\ln w_{\mathrm{i}}^{\mathrm{t}}=\alpha+\mathrm{X}_{\mathrm{i}}^{\mathrm{t}} \beta^{\mathrm{t}}(\theta)+u_{\mathrm{i}}^{\mathrm{t}} \quad i=1, \ldots, N \text { and } t=1987-2008
$$

where $\ln w_{i}^{t}$ is the natural logarithm of the salary of worker $i$, in year $t . X_{i}^{t}$ is the vector of exogenous variables plus the constant $\alpha ; \beta^{t}$ is a vector of parameters, $\theta$ is the quantile being analysed and $u_{i}^{t}$ is an idiosyncratic error term. The vector $X_{i}^{t}$ includes the individual characteristics of levels of education (a variable that comprises five levels - no schooling or primary incomplete; primary complete; secondary; upper secondary and higher or tertiary); potential experience ${ }^{14}$ and potential experience squared; gender (female and male*); marital status (married*, single and other); occupational controls (professionals and technicians, agricultural workers, senior directors and supervisors, operators and transport workers, salespersons and personal service workers and salary earners*); sectors of activity (Agriculture, Forestry, Fishing and Mining Sector, Industry and Manufacturing Sector* including Electricity, Gas Steam, Air Conditioning and Water Supply; Construction, Trade; Transport, Storage and Communications Sector; Services Sector including Financial Services); firm size (micro*, small, medium and large ${ }^{15}$, geographical controls for each of the 38 urban areas (Mexico City*), and time dummies are included taking 1987 as the base year. ${ }^{16}$ Following Koenker and Bassett (1978) and Koenker and Hallock (2001), we use quantile regressions to analyse the wage structure and the decomposition of inequality.

\footnotetext{
${ }^{14}$ There is no information on actual working experience and, thus, in line with many studies we calculate potential experience as 'age-years in education minus 6' and is replaced by age as an explanatory variable.

${ }^{15}$ Small and medium-sized enterprises (SMEs) are classified according to the number of employees (10, 50, 250 and more than 250, respectively) into micro, small, medium, and large enterprises. Economic Census, INEGI.

${ }^{16}$ The $(*)$ represents the base category in each variable.
} 


\subsection{Decomposition of Changes in the Wages}

In this subsection, we explain the strategy used to analyse the effects of covariates on wage inequality using Melly's (2005) decomposition methodology. This decomposition analyses whether changes in wage inequality are driven mainly by changes in characteristics, the composition effect of the workforce or the variance of residuals. Taking as our starting point the results from the quantile regressions, the implementation is straightforward. First, we estimate quantile regressions separately for each year for $\hat{\mathrm{q}}$ with $\theta=0.10,0.25,0.50,0.75,0.90$. Second, we keep the coefficients for each quantile and year. ${ }^{17}$ Third, we calculate counterfactuals based on the endowment distribution for one year using the estimated coefficients for a different year (for example, to calculate the change in inequality in quantile $\theta$ caused by changes in quantities between two years). ${ }^{18}$ Having derived the quantile parameters $\beta(\theta)$, we estimate the marginal distribution of wages as a function of both $X$ and $\beta(\theta)$ and, next, we derive the counterfactual distribution of wages maintaining the covariates at the 1987 level and coefficients at the 2008 level. Autor et al. (2005) and Melly (2005) define the coefficients component as a measure of between-group inequality. In particular, by taking the median as a measure of the central tendency of a distribution, it is possible to derive the wage equation for each year (1987 and 2008):

$$
\ln w_{\mathrm{i}}^{\mathrm{t}}=\alpha+\mathrm{X}_{\mathrm{i}}^{\mathrm{t}} \beta^{\mathrm{t}}(0.5)+u_{\mathrm{i}}^{\mathrm{t}} \quad t=1987-2008
$$

where $\beta^{t}(0.5)$ is the coefficient vector of the median regression in year $t$, which represents a measure of between-group inequality. To disentangle the effect of coefficients (between-group inequality) from that of residuals (within-group inequality) note from (1.1) that the $\theta$ th quantile of the residual distribution of

\footnotetext{
${ }^{17}$ Melly explains that assuming traditional restrictions of the quantile regression model, one can prove that $\hat{q}$ is a consistent and asymptotically normally distributed estimator of $q_{0}$. Given the difficulty in estimating the asymptotic variance, the statistical inference will be conducted with bootstrap procedures. A formal proof and the asymptotic variance can be found in Melly (2006). ${ }^{18}$ Estimating the $\theta$ th quantile of $y$ requires a two-step procedure: 1) estimation of the whole quantile regression process $y=x \beta(\tau)$ and 2 ) estimation of the $\theta$ th quantile sample by weighting each observation by $\left(\tau_{j}-\tau_{j-1}\right)$. The weights are not necessary if a regular grid of quantiles has been used (Melly, 2005).
} 
$u_{\mathrm{i}}^{\mathrm{t}}$ conditionally on $X$ is consistently estimated by $\chi\left(\hat{\beta}^{\mathrm{t}}(\theta)-\hat{\beta}^{\mathrm{t}}(0.5)\right) \cdot{ }^{19}$ Accordingly, Melly (2005) defines the within component using the following vector of coefficients: $\hat{\beta}^{\mathrm{m} 2008, \mathrm{r} 1987}\left(\theta_{\mathrm{j}}\right)=$ $\left(\widehat{\beta}^{2008}(0.5)+\widehat{\beta}^{1987}\left(\theta_{\mathrm{j}}\right)-\widehat{\beta}^{1987}(0.5)\right)$, where the consistent estimate of the residual component given $X,\left(\hat{\beta}^{1987}(\theta)-\widehat{\beta}^{1987}(0.5)\right)$, is added to the between component, $\widehat{\beta}^{2008}(0.5)$. Using counterfactual distributions generated by applying different sets of covariates and coefficients, Melly (2005) computes how the variation over time of some quantile $q$ of the wage distribution is attributable to covariates, coefficients, and residuals. Specifically, Melly estimates the residual component as the difference, at the quantile $q$, of the following two distributions, $\widehat{\mathrm{q}}\left(\widehat{\beta}^{2008}, \chi^{2008}\right)$ and $\hat{\mathrm{q}}\left(\widehat{\beta}^{\mathrm{m} 2008, \mathrm{r} 1987}, \chi^{2008}\right)$, where the $\mathrm{X}$ and the $\beta^{\mathrm{t}}(\theta)$ are constant at the 2008 level whereas the residual inequality is the only one that changes over time. ${ }^{20}$ Similarly, the difference between $\widehat{\mathrm{q}}\left(\widehat{\beta}^{\mathrm{m} 2008, \mathrm{r} 1987}, \chi^{2008}\right)$ and $\hat{\mathrm{q}}\left(\widehat{\beta}^{1987}, \chi^{2008}\right)$ is due to changes in coefficients as characteristics and residual are kept at the 2008 level. Finally, the difference between $\widehat{\mathrm{q}}\left(\widehat{\beta}^{1987}, \chi^{2008}\right)$ and $\widehat{\mathrm{q}}\left(\widehat{\beta}^{1987}, \chi^{1987}\right)$ is due to changes in covariates.

To sum up, by adding and subtracting $\mathrm{q}\left(\widehat{\beta}^{1987}, \chi^{2008}\right)$ and $\mathrm{q}\left(\widehat{\beta}^{\mathrm{m} 2008, \mathrm{r} 1987}, \chi^{2008}\right)$ it is possible to decompose the variation over time of an estimated quantile of wage distribution into three components (residuals, coefficients and covariates), as follow: ${ }^{21}$

\footnotetext{
${ }^{19}$ Note that it is possible to apply the conditional quantile process to (1.1), deriving: $\mathrm{Q}_{\theta}(\mathcal{U} \mid \mathcal{X})=\mathrm{Q}_{\theta}(\mathrm{w} \mid \mathcal{X})-\chi \beta(0.5)=x \beta(\theta)-\chi \beta(0.5)$.

${ }^{20}$ The difference for each quantile $\mathrm{q}$ between the two distribution $\hat{\mathrm{q}}\left(\hat{\beta}^{2008}, \chi^{2008}\right)$ and $\hat{\mathrm{q}}\left(\widehat{\beta}^{\mathrm{m} 2008, \mathrm{r} 1987}, \chi^{2008}\right)$ can be rewritten as $\left\{\widehat{q}\left(\widehat{\beta}^{2008}(0.5)+\hat{\beta}^{2008}\left(\theta_{j}\right)-\widehat{\beta}^{2008}(0.5), \chi^{2008}\right)-\hat{q}\left(\hat{\beta}^{2008}(0.5)+\widehat{\beta}^{1987}\left(\theta_{j}\right)-\hat{\beta}^{1987}(0.5), \chi^{2008}\right)\right\}$, from which it clearly emerges that the only component that changes over time is the residual one, thereby also providing an intuition for the choice of the definition of the within coefficient $\widehat{\beta}^{\mathrm{m} 2008, \mathrm{r} 1987}$.

${ }^{21}$ Note that the sum of the three components amounts exactly to the estimated variation over time of that given quantile. This property is not shared with the previously adopted methodology. Moreover, this decomposition is less restrictive than the Juhn, Murphy and Pierce decomposition because the characteristics are allowed to influence the whole conditional distribution of $Y$.
} 


$$
\begin{aligned}
& \widehat{\mathrm{q}}\left(\widehat{\beta}^{2008}, \chi^{2008}\right)-\left(\widehat{\beta}^{1987}, \chi^{1987}\right)= \\
& \left(\widehat{q}\left(\widehat{\beta}^{2008}, \chi^{2008}\right)-\widehat{q}\left(\widehat{\beta}^{m 2008, r 1987}, \chi^{2008}\right)\right) \\
& +\left(\widehat{\mathrm{q}}\left(\hat{\beta}^{\mathrm{m} 2008, \mathrm{r} 1987}, \chi^{2008}\right)-\hat{\mathrm{q}}\left(\hat{\beta}^{1987}, \chi^{2008}\right)\right) \quad \text { Coefficients } \\
& +\left(\hat{\mathrm{q}}\left(\widehat{\beta}^{1987}, \chi^{2008}\right)-\hat{\mathrm{q}}\left(\widehat{\beta}^{1987}, \chi^{1987}\right)\right) \quad \text { Covariates }
\end{aligned}
$$

Similarly, it is also possible to decompose the variations of all the inequality indexes we are interested in, including the ratios $90 / 10,90 / 50$ and 50/10.

\section{Results}

\subsection{Quantile regression results}

To provide a more detailed picture of the evolution of the wage structure in urban areas in Mexico, we estimate earnings functions during the period under examination (1987-2008), ${ }^{22}$ with an emphasis on labour market developments.. According to the Lemieux framework (2002a, 2006), the increase in the number of educated workers at the bottom of the job and wage distributions is associated with an increase in wage dispersion, which cannot be captured solely by analysing education and experience. Thus, we seek to identify the forces that contribute to modify the wage structure in addition to the education variables. To do this, we aggregate other socio-demographic variables and characteristics of employment, the economic sector, firm size and location in urban areas of the labour force.

\footnotetext{
${ }^{22}$ As mention above, the inequality before and after the peso crisis presented different trends related to the rapid changes in the structure of the labour market, education, and the composition and location of the work force in urban areas.
} 
The first aspect to note is that the coefficients of education and the covariates at all quantiles in the distribution can be thus estimated. Tables 2 and 3 show the results over the time span of the OLS, quantile and interquantile models. ${ }^{23}$ The information contained in Figures 3 to 7 provides a summary of the impact of each covariate upon wage inequality. Specifically, we aim to show the results of the returns of the covariates related to education levels, marital status, gender, potential experience, occupations, economic sector and the firm size gauged by OLS and quantile regressions at the $10^{\text {th }}, 25^{\text {th }}, 50^{\text {th }}, 75^{\text {th }}$ and $90^{\text {th }}$ percentiles.

\section{TABLES 2 and 3}

Table 2 presents the returns to different levels of education and to the other controls. The intercept term represents the log wage distribution of the base group - primary educated, married workers, salary earners, employed in the industrial and manufacturing sector in micro firms located in Mexico City and with 1987 as the base year. As expected, wages increase with the level of education, in particular secondary, upper secondary and higher or tertiary education increases the wage by a significant amount. However, returns decrease in the case of workers with no schooling or incomplete primary studies. From 1987 to 2008 , the unschooled workers were paid, on average, around $14.6 \%$ less in real terms than workers with primary level education, while the returns to secondary, upper secondary and higher or tertiary levels were $16.4 \%, 38.6 \%$ and $78.5 \%$ higher than the base group in real terms, respectively. The returns to the different levels of education are uniform across the distribution, while the returns to higher or tertiary education levels are greater in the higher quantiles. In the case of the results by year, we find that from 1987 to 1994 the returns clearly increased. In subsequent years the returns present slight differences but a decreasing trend. For instance, the contribution made by the returns to higher or tertiary

\footnotetext{
${ }^{23}$ Full model results, including detailed tables per year and figures, are available upon request from the authors.
} 
education to within group inequality strengthened between 1996 and 1997 at the four different levels of education (as returns became more heterogeneous), as shown in Figure 3

\section{FIGURE 3}

Our examination of the effects of demographic variables on wages shows that female workers, both single and separated, are paid significantly less over time and across the distribution, although the disadvantages are most evident in the higher quantiles. In addition to gender there are few other demographic characteristics that play such an important role in wage determination. The disadvantages faced by female workers fell between 1991 and 1996 and between 2002 and 2006. However, at the $75^{\text {th }}$ and $90^{\text {th }}$ quantiles, the effect was more marked than at the bottom of the distribution. This finding is contrary to the perception that increased competitiveness reduces the disadvantages of the female work force (see Figure $4)$.

\section{FIGURES $4 \mathrm{a}$ to $4 \mathrm{f}$}

City coefficients display interesting patterns of heterogeneity in terms of their rates of return. The demographic shifts in Mexico have both direct and indirect effects on wage distribution over time. And most of the effects of the regional dummies are statistically significant if we compare them to Mexico City. Summarising the results in terms of percentages, five points of impact (positive or negative) were chosen: from 1-5, 5.01-10,10.01-15, 15.01-20 and 20.01 and above. We found that the returns to Chihuahua, Saltillo and Culiacán were small, ranging from approximately 0.8 to 4.9 per cent, whereas in cities such as Morelia, Colima, Monclova and Aguascalientes the impact was negative, from -1.2 to -4.3 per cent. In Hermosillo, León, Guadalajara, and Querétaro, the return was in the range of 5.4 to 8.4 per cent, whereas in Coatzacoalcos, Villahermosa, Tepic, San Luis Potosí, Tampico, Puebla, Cuernavaca, Toluca, Torreón and Celaya it was negative, ranging from -5.7 to -9.9 per cent. A broader pattern of 
growth in certain economic sectors played an important role in increasing returns in cities such as Ciudad Juárez, Monterrey and Nuevo Laredo (values hovering between 12.9 and 14.9 per cent), and Tijuana and Matamoros (around 24.6 and 38.2 per cent, respectively). These are in contrast to city areas that reported negative rates of return, such as Irapuato, Veracruz and Durango (with values ranging from -12.6 to -13.1 per cent; Acapulco, Mérida and Zacatecas (ranging from -15.3 to -19.4 per cent); while Tuxtla Gutiérrez, Orizaba, Campeche and Oaxaca hovered around -21 and -32 per cent. These results are indicative of high levels of inequality and poverty in these cities and of substantial observed differences when compared with Mexico City (or with Mexico's border cities). The workers residing in these cities are paid significantly less over time and across the distribution, though the disadvantage is most pronounced in the quantiles at the bottom of the distribution. In addition, these results point to the heterogeneous relationship between economic activity in the urban areas and the location of the labour force. For example, cities with sizeable industrial activity, such as Monterrey or cities near the border like Ciudad Juárez, Tijuana, Matamoros and Nuevo Laredo, present larger wage effects, which have a marked impact on wage determination. These results are consistent with findings in studies of inequality in which geographical variables are aggregated in regions, and with reports that show that the impact of trade and financial liberalization in Mexico generated significant regional differences in terms of income inequality (see, for example, Hanson, 2003 and Popli, 2011). If we observe the results across the distribution in each year, we see that regional variations continue to exert an upward pressure on inequality in the bottom and mid portions of the wage distribution, particularly. The changes exhibit a somewhat irregular pattern, with more substantial changes often being concentrated in quite short time lapses.

Some occupational category dummies are statistically significant over time throughout the distribution (Table 2). A positive wage premium is paid to professionals and technicians as well as to senior directors and supervisors, while a negative wage premium is paid to sales and personal service, and to operators and transport and agricultural workers. From 1987 to 2008, professionals and technicians were paid an average of approximately $35 \%$ more in real terms than was paid to salary earners as a whole, while the returns to 
senior directors and supervisors were $23.2 \%$ (note that in the $75^{\text {th }}$ and $90^{\text {th }}$ percentiles the returns were higher). Figure 5 shows the changes in the effects of the occupations over time and by quantiles. As can be seen from this Figure, there has been little change in the returns of professionals and technicians and the trend is flatter than the others over the period.

\section{FIGURE 5}

Most of the economic sector dummies are also statistically significant, but the impact is not as pronounced as it is for the other covariates. A positive wage premium (with the industry and manufacturing sector as the base category) is paid in service sectors; transport, storage and communication; construction and agricultural, forestry, fishing and mining sectors, while a negative wage premium is paid in the trade sector (see Table 2). These results are consistent with the higher wage premia reported for countries with industries that are capital- or skill-intensive (or both) (Dickens and Katz, 1987; Hasan and Chen, 2003). For most industries, there is no clear pattern in the wage premium across quantiles. Industries that pay a significant and negative wage premium tend to pay it over the entire distribution. There have also been a few changes in industrial structure, as reflected in industry premium (see Figure 6)

\section{FIGURE 6}

As for firm size effects on wages, small firms and medium and large firms are paid significantly more over time and across the distribution than micro firms. From 1987 to 2008, workers employed in small firms and those employed in medium and large firms were paid on average around $11.5 \%$ and $21.8 \%$ more, respectively, in real terms than workers employed in micro firms. Across the distribution and across each year the positive effect of the returns to the small and to the medium and large firms can be observed in Figure 7; the contribution to within group inequality strengthened between 1995 and 1999. Table 5 shows the summary results of estimating interquantile regressions for $90 / 10,90 / 50,50 / 10,75 / 25,75 / 50$ 
and 50/25 percentile ratios. As can be seen, from Table 3, the returns to covariates are statistically significant in most cases, indicating that the covariates introduced in the model have similar effects on wage dispersion to those described above. Specifically, returns to education show a heterogeneous pattern across the conditional distribution of wages, a result confirmed by the magnitude of interquantile differences. ${ }^{24}$ This result strengthens the idea that education gives those located at the top of the wage distribution an advantage, while it also enhances the earnings potential of those located at the bottom. ${ }^{25}$

\section{FIGURE 7}

Tryng to provide an overall synthesis of the obtained results in this section, it is worth mentioning that: first, the level of education increased between 1988 and 1993. Workers with higher or tertiary, upper secondary and secondary levels earned more than their counterparts with primary level, while workers with no schooling or incomplete primary studies earned less than workers in all the other categories (negative coefficients). Moreover, this educational gap increases as we move up through the wage distribution. This implies that the wage distribution for lower levels of education is less dispersed than that for higher or tertiary and upper secondary levels. The negative sign associated with workers with no schooling or incomplete primary studies, therefore, indicates that a larger proportion of workers with that level of education contribute towards reduced wage inequality. Second, returns for unskilled and skilled workers rose in the early 1990s. In line with the trend in overall inequality, however, returns to skilled workers have fallen since the period 1995 to 1998.

\footnotetext{
${ }^{24}$ To analyse the interquantile differences, Buchinsky (1994) outlines how the test of the interquantile differences is performed after an interquantile regression, which reestimates the model taking the difference between the coefficients across the wages distribution $\beta_{X \theta 1-} \beta_{X \theta 2}=0$, where $\theta_{1}$ and $\theta_{2}$ are two distinct quantiles.

${ }^{25}$ This is consistent with the existence of a negative correlation between the marginal costs and marginal benefits of education across the abilities.
} 


\subsection{Decomposition of changes in wage distribution}

We apply the procedure described above to a decomposition of the changes in the wage structure (1987 to 2008) into those attributable to covariates (individual workers' attributes), those attributable to coefficients (the remuneration of these attributes), and those attributable to a residual component. Figure 8 plots the decomposition results at 999 different quantiles placed on the x-axis and Figure 9 shows the total residual effect in the decomposition. Table 4 shows the results of the decomposition. Specifically, we report the estimated variation over time of selected quantiles $(10,25,50,75,90)$, and the related decomposition into the three components. ${ }^{26}$ From the first row of Table 6 it can be noted that the upper tail of the distribution increases (the $75^{\text {th }}$ and the $90^{\text {th }}$ percentile), whereas the $10^{\text {th }}$, median and the $75^{\text {th }}$ percentile decrease substantially over time.

TABLE 4

FIGURES 8 and 9

As for the decomposition components, it emerges that the coefficients component (between) in the $75^{\text {th }}$ and the $90^{\text {th }}$ percentile is negative and increases in magnitude, ranging from -0.064 at the $75^{\text {th }}$ percentile to -0.144 at the $90^{\text {th }}$ percentile. This indicates that the decline in the price of human capital will have generated a shift to the left of the wage schedule, concentrated mainly in the right tail of the distribution, for constant covariates and the residual components. This negative coefficients component is consistent with the dynamics of educational wage premia in Mexico. Thus, educational wage premia decreased

\footnotetext{
${ }^{26}$ Note that the estimated variations at the selected quantiles fit the observed variations and the inequality indexes well. This provides additional support for the benefits of the quantile decomposition method.
} 
across the whole wage distribution in the period 1987-2008 in line with earlier reports provided by Airola and Juhn (2005), López-Acevedo (2006), Campos-Vázquez (2008) and Popli (2011).

As for the covariates component, this is positive at the $10^{\text {th }}$ and $25^{\text {th }}$ percentiles and decreases in magnitude from 0.148 at the $10^{\text {th }}$ percentile to 0.075 at the $25^{\text {th }}$ percentile, whereas the median, the $75^{\text {th }}$ and the $90^{\text {th }}$ percentiles are negative and increase substantially over time. The negative effect of characteristics on the median indicates that if workers' attributes had been rewarded at the same rate in 2008 as in 1987, wages would have fallen, not risen, in 2008 . The residual contribution is negative at the lower tail of the distribution from the $10^{\text {th }}$ percentile to the median, and becomes decidedly relevant at the upper tail of the distribution (in particular at the $90^{\text {th }}$ percentile).

These findings regarding the variations of selected quantiles of the wage distribution help to shed light on the dynamic relationship between the human capital attainments of the work force and wage inequality (Autor et al., 2005; Melly, 2005). In fact, the standard inequality indexes (90/10, 90/50, 50/10) are easily derived from Table 4, allowing us to compute the related ratios both for the estimated variations and for the three components. We observe that the upper tail (90/50) of the wage distribution increases, while a wage compression is observed in the lower tail, i.e., the 50/10 index decreases since the wages of the lowskilled group $\left(10^{\text {th }}\right)$ declined less than those of individuals around the median wage level.

Considering the impact of the decomposition components on wage inequality, from Table 4 we show that the coefficients (between) effect is negative in the changes of three ratios, while that of 90/50 is less than that of the 90/10 and 50/10 ratios. This negative price effect is reinforced by a relevant negative covariates component. As for the within component, we observe a significant positive impact on the lower tail of the wage distribution and to a lesser extent in both the 90/10 and 90/50 inequality indexes. 
The extent to which the positive residual component offsets both the negative coefficients and covariates components depends on their relative magnitudes across the wage distribution. In fact, the falling 50/10 ratio is mainly explained by the negative covariates and coefficients components, while the residuals inequality drives the increases in wage inequality at the top of the wage distribution. Specifically, the 90/50 index increase is related to the residual component, while the stability of the $90 / 10$ index is explained by negative coefficients and covariates effects that are counterbalanced by a positive residual component.

In order to provide an interpretation of the within component, we resort to 'skill price theory' (Juhn et al., 1993; Lemieux, 2002b), which basically underlines two main effects: on the one hand, the positive (negative) changes in the coefficients component which exerts a positive (negative) impact on the residual component throughout the wage distribution, thereby providing a measure for 'unmeasured price skills'; and, on the other hand, the residual component, i.e., the proportion of educated and experienced workers in the labour force. Our results (reported in Table 4) suggest that up to the 75th percentile these two forces cancel each other out (involving a within component close to zero), while at the $90^{\text {th }}$ and $95^{\text {th }}$ percentiles the positive effect related to the characteristics of the workers seems to prevail over the negative effect induced by the coefficients component. In terms of wage inequality, this implies that the within inequality plays an important role in the upper tail of the distribution, as stressed earlier.

To sum up, the picture that emerges from these decomposition exercises can be explained by the fact that labour demand would seem to have increased at a lower rate than labour supply: in 2008, workers employed in the labour market were more highly educated than their counterparts in 1987, but the former received lower wages for the same level of education. In other words, the evidence we present suggests that in Mexico we do not observe the standard features related to a skill-biased change, usually defined as a situation in which an increase in the relative demand for skilled workers exceeds the increase in supply. 
This also means that in Mexico the choice of schooling could have been crowded out by the contents of the productive process.

\section{Concluding remarks}

In this paper, we have investigated the relationship between wage structure, inequality and skill-biased change in Mexico, an outlier in the literature examining the links between changes over time in wage inequality and the distribution of schooling wage premia. We have presented a method to decompose the changes in the wage distribution over a period of time into the various factors that contribute to these changes based on Melly's (2005) quantile decomposition approach which uses a semiparametric estimator of distribution functions in the presence of covariates. The conditional wage distribution is estimated by quantile regression. The conditional distribution is then integrated over the range of the covariates to obtain estimates of the unconditional distribution. Counterfactual distributions can be estimated, allowing the decomposition of changes in the distribution into three factors: changes in the regression coefficients, changes in the distribution of covariates and changes in the residuals. We have applied this methodology to Mexico urban data for the period 1987-2008, a period during which earnings inequality presented varying trends. Thus, between 1987 and 1994, there was an increase in wage inequality, but then in the period after 1994, and unlike many developed countries, Mexico presented a declining wage inequality.

Our estimates suggest that changes both in individuals' attributes and in the returns to these attributes contributed in different directions to the increases and decreases observed in wage inequality over time. Moreover, the contributions of the two changes varied in magnitude depending on the section of the wage distribution under analysis. It is claimed that raising education serves to reduce wage inequality; however, our analysis, by contrast, suggests that in Mexico increases in educational levels do not necessarily result in a more equitable wage distribution. Thus, even though educational levels rose rapidly and educational 
inequality is the variable that accounts for the largest share, by far, of wage inequality in Mexico, there remains considerable heterogeneity among the workers in terms of their educational level.

The marginal contribution made by education in explaining inequality in Mexico is virtually equal to the joint contribution of other relevant variables that include occupation, economic sector, firm size and urban areas. It should be stressed, however, that the difference in the marginal contributions has increased over time, indicating that, as the economy progresses, education acquires greater importance in determining the choice of sector, occupation and firm size. Moreover, the contribution of relevant variables to changes in inequality for different intervals of time are related to changes in the covariates, coefficients (the between effect) and residuals (the within effect) in urban areas.

In general, across quantiles the returns to education are positive for workers with secondary, upper secondary and higher or tertiary levels of education, while at levels below that (primary and no schooling) they are negative. Additionally, the education-wage profile indicated by the coefficients of the education dummies has become steeper over time. Indeed, we have highlighted differences in the returns to education in different points of the distribution (Figure 1). The gap between the returns to education levels has increased, with most of the increase being attributable to a decline in the returns to lower skilled groups. Finally, the evidence on educational dynamics in Mexico is mixed. On the one hand, there was a modest reduction in the gap between the top and bottom quintiles of workers. The average schooling improved somewhat, but the inequality of the distribution of education deteriorated, whereas the wage profile, which is related to the returns to schooling, became much steeper. This means that there was a shift in demand toward highly skilled labour that was not met by an increase in supply.

The returns to education in Mexico from 1987 to 1997 increased for higher levels of education and in the upper tail of the conditional wages distribution; however, there was a reversal in this trend after 1997, especially for the upper secondary and tertiary education as expanding relative supplies of school-leavers 
seem to offset the secular tendency for rising relative demand for skills (see De Ferranti et al., 2004). Alternatively, it may reflect a cyclical fall in education premia in times of recession.

Our results suggest that the evolution taken by wages inequality in Mexico is not the result of changes in the distribution of education, whereas the wage profile, which is related to returns to schooling, is a key force in accounting for the country's inequality. There may be many reasons for this: the education system, the minimum wage, the demography of the firms might all play a role. In the light of this evidence, we have analysed the structure and evolution of the rates of returns to education and other controls that are important in the wage structure. ${ }^{27}$

In sum, our evidence reveals significant differences in terms of worker characteristics at different points in the distribution and highlights transient effects over time: educational levels, gender, experience, occupation, economic sector, firm size and urban areas are important factors that affect the wage distribution throughout the period studied. The increase in wage inequality between 1987 and 2008, above all at the bottom of the distribution, can be explained by a declining real wage. Thus, in short, inequality varies not just between these different groups, but it is also seen to differ within groups of workers.

\footnotetext{
${ }^{27}$ Hanson and Harrison (1995) examine the impact of Mexican trade reform on the structure of wages using information at the firm level and the relation with the relative use of skilled labour. They conclude that the wage gap is associated with changes within industries and firms, which cannot be explained by the Stolper-Samuelson type effects. López-Acevedo (2006) concluded that the increase in wage inequality was due to other factors and that an aggregate of controls are consistent with the idea that market access is important for the location of industry.
} 


\section{References}

Airola, J., and Juhn, C. (2005), 'Wage inequality in Post-Reform Mexico', IZA Discussion Paper no. 1525.

Atkinson, A.B. (2008), 'More on the measurement of inequality', Journal of Economic Inequality, 6: 277283.

Autor, D.A, Katz, L.F., and Kearney, M.S. (2005), 'Rising Wage Inequality: The Role of Composition and Prices', NBER no. 11628.

Autor, D. A., Katz, L. F., and Kearney, M. S. (2008). 'Trends in U.S. wage inequality: revising the revisionists', The Review of Economics and Statistics, 90(2): 300-323.

Beyer, H., Rojas, P., and Vergara, R. (1999), 'Trade liberalization and wage inequality', Journal of Development Economics, 59(1): 103-123.

Blinder, A. S. (1973), 'Wage discrimination: reduced form and structural estimates', The Journal of Human Resources, 8(4): 436-455.

Bound, J., and Johnson, G. (1992), 'Changes in the Structure of Wages in the 1980's: An Evaluation of Alternative Explanations', The American Economic Review, 82(3): 371-392.

Bourguignon, F., and Martinez, M. (1997), 'Decomposition of the Changes in the Distribution of Primary Family Income: A Microsimulation Approach Applied to France, 1979-1989’ DELTA, Working Paper.

Bourguignon, F., Fournier, M., and Gurgand, M. (1998), 'Labor Incomes and Labor Supply in the Course of Taiwan's Development, 1979-1994', DELTA, Working Paper.

Buchinsky, M. (1994), 'Changes in the U.S. Wage structure 1963-1987: Application of Quantile Regression', Econometrica, 62(2): 405-458.

Campos-Vázquez, R. M. (2008), 'Why did wage inequality decrease in Mexico after NAFTA?', Mimeo, University of California-Berkeley.

Campos-Vazquez, R. M. (2010), 'Why did wage inequality decrease in Mexico after NAFTA?', Serie documentos de trabajo no. XV, CEE. Colmex.

Currie, J., and Harrison, A. (1997), Sharing the Costs: The Impact of Trade Reform on Capital and Labor in Morocco', Journal of Labor Economics, 15(3): S44-S71.

De Ferranti, D., G. Perry, M. Walton and F. Ferreira. (2004), Inequality in Latin America: Breaking with History? Washington: The World Bank.

De Hoyos, R. (2007), 'Accounting for Mexican Income Inequality during the 1990s', World Bank Working Paper no. 4225. 
Dickens, W. T., and Katz, L. F. (1987), 'Inter-industry wage Differences and Industry Characteristics', in Kevin Lang and Jonathan S. Leonard, eds., Unemployment and the Structure of Labor Markets (New York, NY: Basil Blackwell).

DiNardo, J., Fortin, N. M. and Lemiux, T. (1996), 'Labour Market Institutions and the Distribution of Wages, 1973-1992: A Semiparametric Approach', Econometrica, 64(5): 1001-1044.

Duryea, S. and Székely, M. (1998), 'Labor markets in Latin America: A Supply-side Story', Working Paper no. 374, Inter-American Development Bank, Office of the Chief Economist.

Esquivel, G., Lustig, N., and Scott, J. (2010), 'Mexico: a decade of falling inequality: market forces or state action?' in: L. F. López-Calva and N. C. Lustig (Eds) Declining Inequality in Latin America: A Decade of Progress? (Brookings Institution Press).

Esquivel, G. (2009), 'The dynamics of income inequality in Mexico since NAFTA', Research for Public Policy, Inclusive Development, ID-02-2009, RBLAC-UNDP, New York.

Fitzenberger, B., and Kurz, C. (2003), 'New Insights on Earning trends across Skill groups and Industries in West Germany', Empirical Economics, 28(3): 479-514.

Fortin, N., Lemieux, T., and Firpo, S. (2011), 'Decomposition Methods in Economics', in: Ashenfelter, O, Card, D (eds.): Handbook of Labor Economics, Vol 4(4). Elsevier.

González, X., and Miles, D. (2001), 'Wage Inequality in a Developing Country: Decrease in Minimum Wage or Increase in Education Returns', Empirical Economics, 26(1): 135-148.

Goos, M., and Manning, A. (2007), 'Lousy and Lovely Jobs: The Rising Polarization of Work in Britain', The Review of Economics and Statistics, 89(1): 118-133.

Hasan, R., and Chen, L. (2003), 'Trade and Workers: Evidence from Philippines', Economic Study Area, Working Paper no. 61.

Hanson, G. H. (2003), 'What has Happened to Wages in Mexico since NAFTA?', in FTAA and Beyond: Prospects for Integration in the Americas, ed. by T. Estevadeordal, D. Rodrik, A. Taylor, and A. Velasco. Harvard University Press, Cambridge.

Hanson, G. H. and Harrison, A. (1999), 'Trade liberalization and wage inequality in Mexico', Industrial and Labor Relations Review, 52(2): 271-288.

Hanson, H., and Harrison, A. (1995), 'Trade, Technology, and Wage Inequality', Working Paper no. 5110. National Bureau of Economic Research. Cambridge, Mass. Processed.

Juhn C., K. Murphy, and Pierce, B. (1993), 'Wage Inequality and the Rise in Returns to Skill', Journal of Political Economy, 3(3): 410-442.

Kijima, Y. (2006), 'Why did Wage Inequality Increase? Evidence from Urban India 1983-99', Journal of Development Economics, 81(1): 97-117.

Koenker, R., and Basset, G. (1978), 'Regression Quantiles', Econometrica, 46: 33-50. 
Koenker, R. and Hallock, F. (2001), 'Quantile Regression' Journal of Economics Perspectives, 15(4): 143-156.

Legovini, A., Bouillon, C. and Lustig, N. (2005), Can education explain changes in income inequality in Mexico? in: F. Bourguignon, F. H. G. Ferreira and N. Lustig (Eds.) The Microeconomics of Income Distribution Dynamics in East Asia and Latin America (A co-publication of World Bank and Oxford University Press), pp. 275-312.

Lemieux, T. (2002a), 'Decomposing Changes in Wage Distributions: A Unified Approach', Canadian Journal of Economics, 35(4): 646-688.

Lemieux, T. (2002b), 'Schooling, Experience and Earnings: Twenty Five Years of Mincer Equations', Department of Economics, University of British Columbia.

Lemieux, T. (2006), 'Increased Residual Wage Inequality: Composition Effects, Noisy Data, or Rising Demand for Skill?', The American economic Review, 96(3): 461-498.

Lemieux, T. (2008), 'The Changing Nature of Wage Inequality', Journal of Population Economics, 21(1): $21-48$.

López-Acevedo, G. (2006), 'Mexico: Two Decades of the Evolution of Education and Inequality', World Bank Policy Research, Working Paper no. 3919, The World Bank.

López-Calva, L. F., and Lustig, N. (2009), 'The Recent Decline of Inequality in Latin America: Argentina, Brazil, Mexico and Peru', ECINEQ, Working Papers Series no. 140.

López-Calva, L. F., and Lustig, N. (eds.) (2010), Declining Inequality in Latin America: a Decade of Progress?, Brookings Institution Press and UNDP.

Lustig, N. (1998), Mexico: The Remaking of an Economy, 2nd ed., (Washington, DC: Brookings Institution Press).

Lustig, N. (2001), 'Life is not easy: Mexico's quest for stability and growth', Journal of Economic Perspectives, 15: 85-106.

Machado, J., and Mata, J. (2001), 'Earning functions in Portugal 1982-1994: Evidence from Quantile Regressions, Empirical Economics, 26: 115-134.

Machado, J., and Mata, J. (2005), 'Counterfactual Decompositions of Changes in Wage Distributions Using Quantile Regression', Journal of Applied Econometrics, 20(4): 445-465.

Melly, B. (2005), 'Decomposition of Differences in Distribution Using Quantile Regression', Labour Economics, 12(4): 577-590.

Melly, B. (2006), Applied Quantile Regression. PhD diss., University of St. Gallen.

Meza, L. (1999), 'Cambios en la estructura salarial en Mexico en el periodo 1988-1993 y el aumento en el rendimiento de la educación superior', Trimestre Económico, 49(196): 813-60. 
Mincer, J. (1958), 'Investment in Human Capital and Personal Income Distribution', Journal of Political Economy, 66(4): 281-302.

Mincer, J. (1974), 'Schooling, Experience, and Earnings', NBER, New York.

Oaxaca, R. (1973), 'Male-Female Wage Differential in Urban Labour Market', International Economic Review, 14: 693-709.

Nielsen, H., and Rosholm, M. (2001), 'The Public-Private Sector Wage gap in Zambia? A Quantile Regression Approach', Empirical Economics, 26(1): 169-182.

OECD (2007), Employment Outlook 2007, Paris: OECD.

Popli, G. (2011), 'Changes in Human Capital and Wage Inequality in Mexico', Oxford Development Studies, 39(3): 369-387.

Robertson, R. (2007). 'Trade and Wages: Two Puzzles from Mexico', The World Economy, 30(9): 13781398.

Robbins, D., and Gindling, T. H., (1999), 'Trade Liberalization and the Relative Wages for More-Skilled Workers in Costa Rica', Review of Development Economics, 3(2): 140-54.

Sámano, C. (2010), Programa de gobierno y desigualdad en México: un análisis comparativo 1988-1994 vs 2000-2006, y los determinantes de la desigualdad un enfoque jeráquico. Master's thesis, FLACSO-México.

Tello, C. (2011). Wage inequality: labor markets in Mexico, 1987-2008. University of Barcelona. Mimeo. 


\section{Tables and Figures}

Table 1. Mean of the covariates, 1987-2008

\begin{tabular}{lcccc}
\hline Variable & Log real hourly wage & Years of education & Experience & Experience squared \\
\hline 1987 & 2.79 & 8.76 & 16.38 & 430.98 \\
1988 & 2.77 & 8.95 & 16.17 & 421.63 \\
1989 & 2.85 & 9.11 & 16.01 & 414.34 \\
1990 & 2.89 & 9.19 & 15.86 & 408.11 \\
1991 & 2.88 & 9.33 & 15.77 & 405.53 \\
1992 & 2.91 & 9.52 & 15.85 & 406.62 \\
1993 & 2.96 & 9.73 & 15.76 & 400.16 \\
1994 & 2.99 & 9.82 & 15.85 & 398.28 \\
1995 & 2.79 & 9.96 & 16.01 & 404.07 \\
1996 & 2.65 & 10.00 & 16.12 & 407.02 \\
1997 & 2.66 & 10.17 & 16.00 & 402.22 \\
1998 & 2.69 & 10.08 & 16.19 & 406.77 \\
1999 & 2.69 & 10.09 & 16.33 & 411.78 \\
2000 & 2.80 & 10.19 & 16.55 & 421.51 \\
2001 & 2.88 & 10.31 & 16.80 & 429.96 \\
2002 & 2.90 & 10.43 & 17.12 & 441.36 \\
2003 & 2.93 & 10.52 & 17.30 & 450.04 \\
2004 & 2.93 & 10.63 & 17.32 & 451.69 \\
2005 & 2.90 & 10.54 & 18.09 & 485.16 \\
2006 & 2.96 & 10.61 & 18.12 & 488.12 \\
2007 & 2.98 & 10.79 & 18.22 & 494.04 \\
2008 & 2.95 & 10.87 & 18.31 & 498.77 \\
\hline Source: Authors' own calculations. Results based on data panel ENEU-ENOE surveys from 1987 to 2008. \\
\hline
\end{tabular}

Figure 1. Real hourly wage (log) in Mexico, 1987-2008

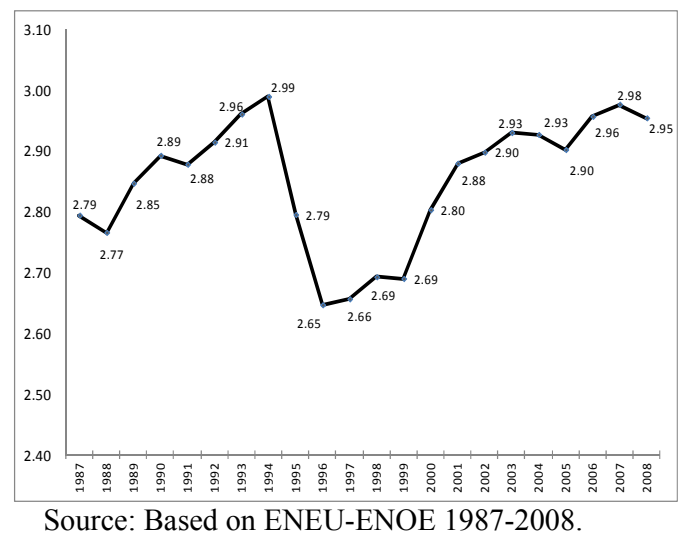

Figure 2. Years of education in Mexico, 1987-2008

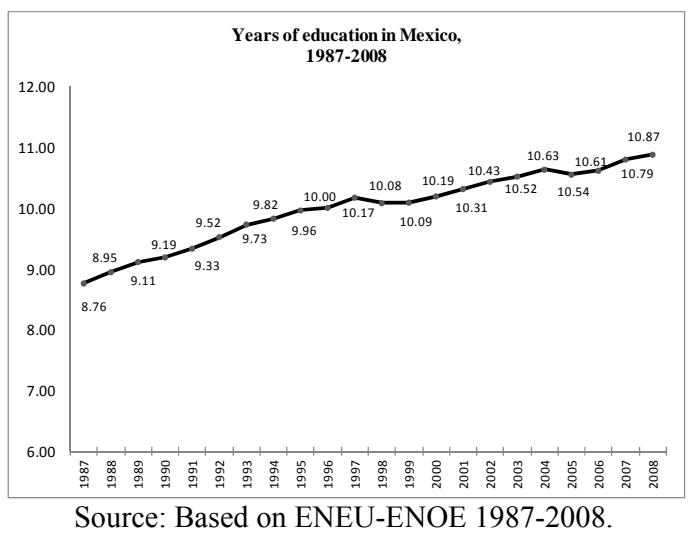


Table 2. OLS and Quantile Regressions, Mexico (1987-2008).

\begin{tabular}{|c|c|c|c|c|c|c|}
\hline & OLS & 10th quant. & 25 th quant. & 50th quant. & 75th quant. & 90th quant. \\
\hline Gender (base: male) & $-0.0788 * * *$ & $-0.044 * * *$ & $-0.062 * * *$ & $-0.082 * * *$ & $-0.106^{* * *}$ & $-0.131 * * *$ \\
\hline \multicolumn{7}{|l|}{ Marital status (base: married) } \\
\hline Single & $-0.115^{* * *}$ & $-0.104 * * *$ & $-0.102 * * *$ & $-0.107 * * *$ & $-0.112 * * *$ & $-0.119 * * *$ \\
\hline Other & $-0.0726^{* * *}$ & $-0.065^{* * *}$ & $-0.069 * * *$ & $-0.074 * * *$ & $-0.077 * * *$ & $-0.074 * * *$ \\
\hline \multicolumn{7}{|l|}{ Education level (base: Primary) } \\
\hline No schooling or primary incomplete & $-0.146^{* * *}$ & $-0.132 * * *$ & $-0.129 * * *$ & $-0.136 * * *$ & $-0.157 * * *$ & $-0.171 * * *$ \\
\hline Secondary & $0.164 * * *$ & $0.119 * * *$ & $0.133 * * *$ & $0.152 * * *$ & $0.176^{* * *}$ & $0.208 * * *$ \\
\hline Upper secondary & $0.386^{* * *}$ & $0.276^{* * *}$ & $0.314 * * *$ & $0.370 * * *$ & $0.434 * * *$ & $0.503 * * *$ \\
\hline Higher or Tertiary & $0.785^{* * *}$ & $0.605^{* * *}$ & $0.697 * * *$ & $0.787 * * *$ & $0.870^{* * *}$ & $0.951 * * *$ \\
\hline \multicolumn{7}{|l|}{ Occupation (base: Salary earners) } \\
\hline Professionals and technicians & $0.350 * * *$ & $0.249 * * *$ & $0.299 * * *$ & $0.357 * * *$ & $0.409 * * *$ & $0.444 * * *$ \\
\hline Agricultural workers & $-0.291 * * *$ & $-0.258 * * *$ & $-0.264 * * *$ & $-0.291 * * *$ & $-0.329 * * *$ & $-0.287 * * *$ \\
\hline Senior directors and supervisors & $0.232 * * *$ & $0.146^{* * *}$ & $0.179^{* * *}$ & $0.220^{* * *}$ & $0.274 * * *$ & $0.313^{* * *}$ \\
\hline Operators and transport workers & -0.003 & $-0.0131 * * *$ & 0.003 & $0.007 * *$ & 0.004 & $0.013 * *$ \\
\hline $\begin{array}{l}\text { Salespersons and personal service } \\
\text { workers }\end{array}$ & $-0.130 * * *$ & $-0.186^{* * *}$ & $-0.157 * * *$ & $-0.131 * * *$ & $-0.099 * * *$ & $-0.064 * * *$ \\
\hline Potential experience & $0.0236^{* * *}$ & $0.0190 * * *$ & $0.021 * * *$ & $0.023 * * *$ & $0.025^{* * *}$ & $0.026^{* * *}$ \\
\hline Potential experience squared & $-0.0004 * * *$ & $-0.0003 * * *$ & $-0.0003 * * *$ & $-0.0003 * * *$ & $-0.0004 * * *$ & $-0.0003 * * *$ \\
\hline \multicolumn{7}{|l|}{$\begin{array}{l}\text { Economic sector (base: Industry and } \\
\text { Manufacturing Sector (1) ) }\end{array}$} \\
\hline $\begin{array}{l}\text { Agricultural, Forestry, Fishing and } \\
\text { Mining Sector }\end{array}$ & $0.190 * * *$ & $0.086^{* * *}$ & $0.118^{* * *}$ & $0.173 * * *$ & $0.252 * * *$ & $0.301 * * *$ \\
\hline Construction & $0.0915^{* * *}$ & $0.126^{* * *}$ & $0.116^{* * *}$ & $0.099 * * *$ & $0.082 * * *$ & $0.063^{* * *}$ \\
\hline Trade & $-0.0289 * * *$ & $-0.019 * * *$ & $-0.021 * * *$ & $-0.026 * * *$ & $-0.031 * * *$ & $-0.034 * * *$ \\
\hline $\begin{array}{l}\text { Transport, Storage and } \\
\text { Communications Sector }\end{array}$ & $0.0798 * * *$ & 0.003 & $0.039 * * *$ & $0.082 * * *$ & $0.132 * * *$ & $0.174 * * *$ \\
\hline Services Sector (2) & $0.0877 * * *$ & $0.050 * * *$ & $0.079 * * *$ & $0.099 * * *$ & $0.113 * * *$ & $0.126^{* * *}$ \\
\hline \multicolumn{7}{|l|}{ Firm size (base: micro) } \\
\hline Small & $0.115^{* * *}$ & $0.137 * * *$ & $0.111^{* * *}$ & $0.098 * * *$ & $0.098 * * *$ & $0.107 * * *$ \\
\hline Medium and Large & $0.218^{* * *}$ & $0.242^{* * *}$ & $0.219^{* * *}$ & $0.208^{* * *}$ & $0.199 * * *$ & $0.183^{* * *}$ \\
\hline Constant & $2.175 * * *$ & $1.795 * * *$ & $1.989 * * *$ & $2.183 * * *$ & $2.387 * * *$ & $2.628 * * *$ \\
\hline
\end{tabular}

Source: Authors' own calculations. Results based on data panel ENEU-ENOE surveys from 1987 to 2008.

$\mathrm{n}=1,372,978$ and $\mathrm{R}$-squared $=0.5$

Notes:

(1) Including Electricity, Gas Steam, Air Conditioning and Water Supply

(2) Including Financial Services

Including regional and temporal effects

Robust standard errors in brackets

$* * * \mathrm{p}<0.01, * * \mathrm{p}<0.05, * \mathrm{p}<0.1$ 
Table 3. Interquantile Regressions, Mexico (1987-2008).

\begin{tabular}{|c|c|c|c|c|c|c|}
\hline & $90 / 10$ & $90 / 50$ & $50 / 10$ & $75 / 25$ & $75 / 50$ & $50 / 25$ \\
\hline Gender (base: male) & $-0.087 * * *$ & $-0.049 * * *$ & $-0.038 * * *$ & $-0.043 * * *$ & $-0.023 * * *$ & $-0.020 * * *$ \\
\hline \multicolumn{7}{|l|}{ Marital status (base: married) } \\
\hline Single & $-0.015 * * *$ & $-0.013 * * *$ & $-0.003 * * *$ & $-0.009 * * *$ & $-0.005 * * *$ & $-0.004 * * *$ \\
\hline Other & -0.009 & 0.0002 & $-0.010 * * *$ & $-0.009 * * *$ & $-0.002 * *$ & $-0.006 * * *$ \\
\hline \multicolumn{7}{|l|}{ Education level (base: Primary) } \\
\hline No schooling or primary incomplete & $-0.039 * * *$ & $-0.034 * * *$ & -0.005 & $-0.029 * * *$ & $-0.021 * *$ & -0.008 \\
\hline Secondary & $0.089 * * *$ & $0.056^{* * *}$ & $0.033 * * *$ & $0.043 * * *$ & $0.024 * * *$ & $0.019 * * *$ \\
\hline Upper secondary & $0.227 * * *$ & $0.133 * * *$ & $0.094 * * *$ & $0.119 * * *$ & $0.064 * * *$ & $0.056^{* * *}$ \\
\hline Higher or Tertiary & $0.346^{* * *}$ & $0.163 * * *$ & $0.183 * * *$ & $0.173 * * *$ & $0.083 * * *$ & $0.090 * * *$ \\
\hline \multicolumn{7}{|l|}{ Occupation (base: Salary earners) } \\
\hline Professionals and technicians & $0.195 * * *$ & $0.087 * * *$ & $0.108 * * *$ & $0.109 * * *$ & $0.052 * * *$ & $0.058 * * *$ \\
\hline Agricultural workers & $-0.029 * * *$ & 0.005 & -0.033 & $-0.065 * * *$ & $-0.038 * * *$ & $-0.028 * * *$ \\
\hline Senior directors and supervisors & $0.168 * * *$ & $0.093 * * *$ & $0.074 * * *$ & $0.094 * * *$ & $0.054 * * *$ & $0.040 * * *$ \\
\hline Operators and transport workers & $0.026^{* * *}$ & $0.006 * *$ & $0.020 * *$ & 0.001 & -0.002 & 0.003 \\
\hline $\begin{array}{l}\text { Salespersons and personal service } \\
\text { workers }\end{array}$ & $0.122 * * *$ & $0.066^{* * *}$ & $0.055 * * *$ & $0.058 * * *$ & $0.031 * * *$ & $0.027 * * *$ \\
\hline Potential experience & $0.007 * * *$ & $0.003 * * *$ & $0.004 * * *$ & $0.004 * * *$ & $0.002 * * *$ & $0.002 * * *$ \\
\hline Potential experience squared & $-0.000014^{* *}$ & $0.000005 * *$ & $-0.000019 * * *$ & $-0.000012 * * *$ & -0.00001 & $-0.000013 * * *$ \\
\hline \multicolumn{7}{|c|}{$\begin{array}{l}\text { Economic sector (base: Industry and } \\
\text { Manufacturing Sector (1) ) }\end{array}$} \\
\hline $\begin{array}{l}\text { Agricultural, Forestry, Fishing and } \\
\text { Mining Sector }\end{array}$ & $0.215^{* * *}$ & $0.128 * * *$ & $0.087 * * *$ & $0.133 * * *$ & $0.079 * * *$ & $0.055 * * *$ \\
\hline Construction & $-0.063 * * *$ & $-0.036 * * *$ & $-0.027 * * *$ & $-0.034 * * *$ & $-0.017 * * *$ & $-0.017 * * *$ \\
\hline Trade & $-0.015^{* *}$ & -0.009 & $-0.007 * *$ & $-0.010 * * *$ & $-0.005 * *$ & $-0.005 * * *$ \\
\hline $\begin{array}{l}\text { Transport, Storage and } \\
\text { Communications Sector }\end{array}$ & $0.171 * * *$ & $0.092 * * *$ & $0.078 * * *$ & $0.093 * * *$ & $0.051 * * *$ & $0.043 * * *$ \\
\hline Services Sector (2) & $0.076^{* * *}$ & $0.027 * * *$ & $0.049 * * *$ & $0.034 * * *$ & $0.014 * * *$ & $0.019 * * *$ \\
\hline \multicolumn{7}{|l|}{ Firm size (base: micro) } \\
\hline Small & $-0.030 * * *$ & $0.009 * *$ & $-0.039 * * *$ & $-0.013 * * *$ & -0.0002 & $-0.013 * * *$ \\
\hline Medium and Large & $-0.059 * * *$ & $-0.026 * * *$ & $-0.033 * * *$ & $-0.020 * * *$ & $-0.009 * * *$ & $-0.011 * * *$ \\
\hline Constant & $0.833 * * *$ & $0.445^{* * *}$ & $0.388 * * *$ & $0.397 * * *$ & $0.204 * * *$ & $0.194 * * *$ \\
\hline
\end{tabular}

Source: Authors' own calculations. Results based on data panel ENEU-ENOE surveys from 1987 to 2008.

$\mathrm{n}=1,372,978$ and $\mathrm{R}$-squared $=0.5$

Notes:

(1) Including Electricity, Gas Steam, Air Conditioning and Water Supply

(2) Including Financial Services

Including regional and temporal effects

Robust standard errors in brackets

$* * * \mathrm{p}<0.01, * * \mathrm{p}<0.05, * \mathrm{p}<0.1$ 
Figure 3. OLS and quantile regression coefficients to education level (1987-2008).

(a)

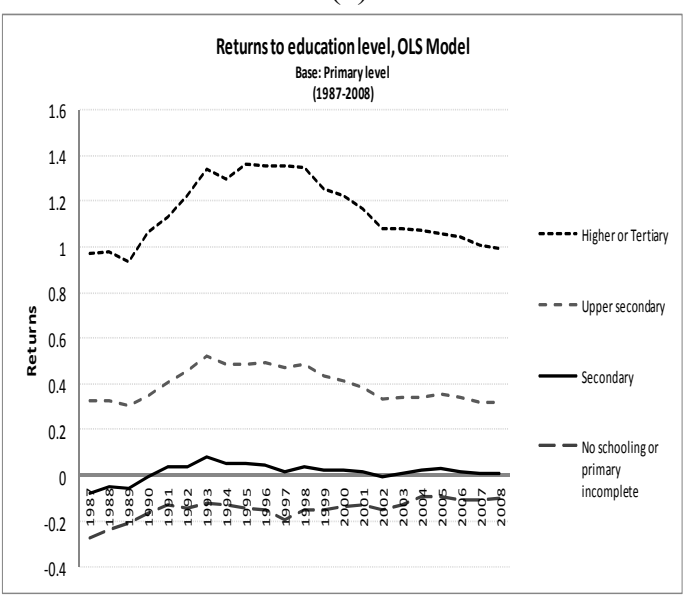

(c)

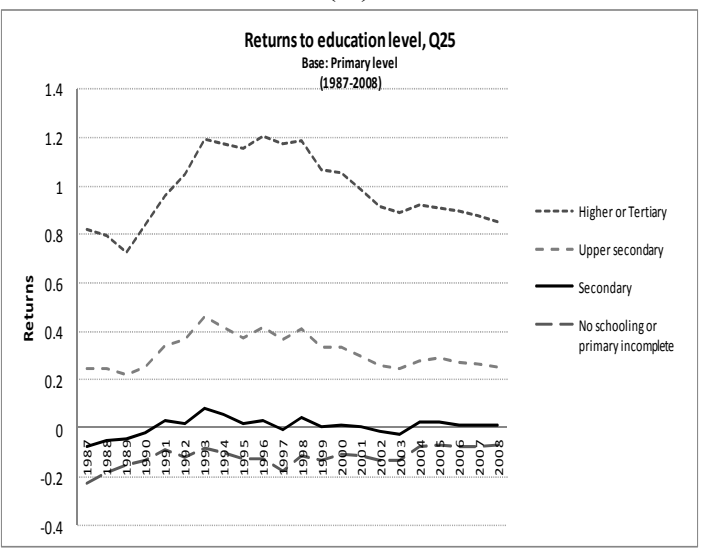

(e)

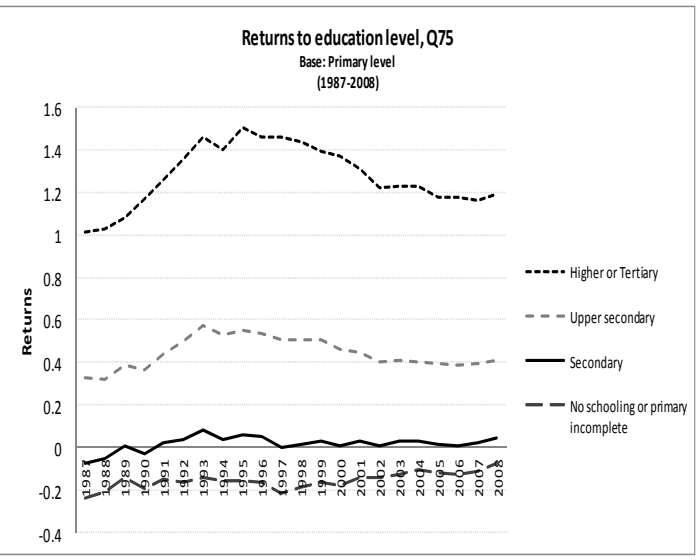

Source: Own elaboration from ENEU-ENOE 1987-2008. (b)

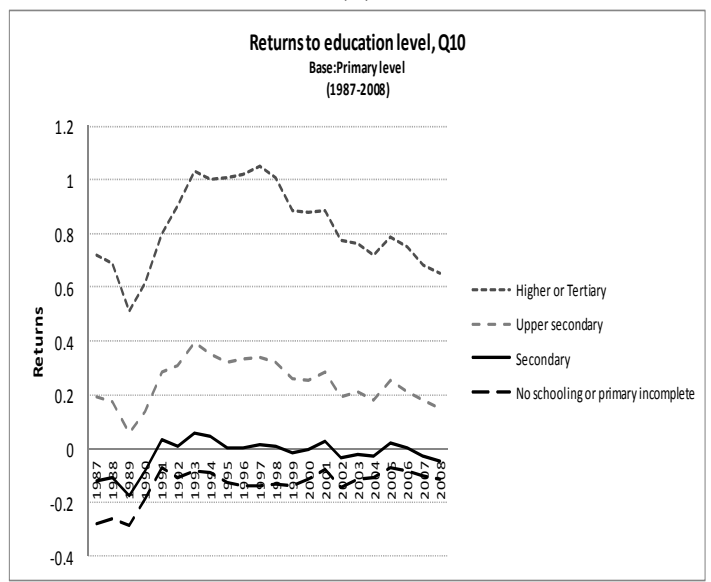

(d)

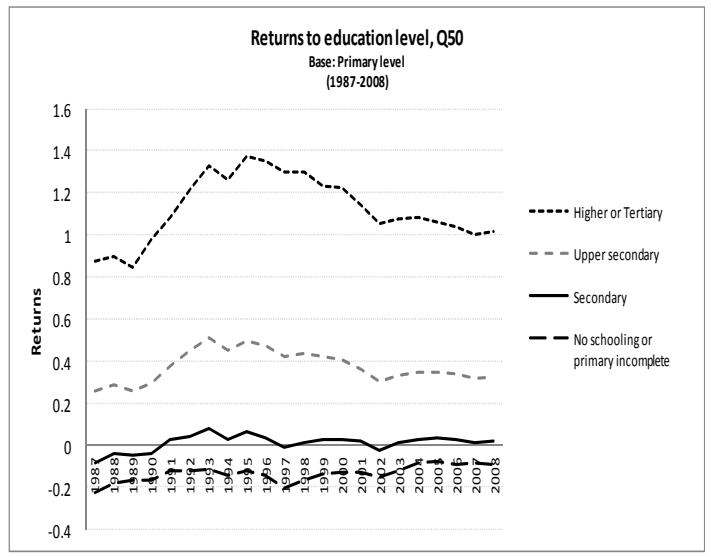

(f)

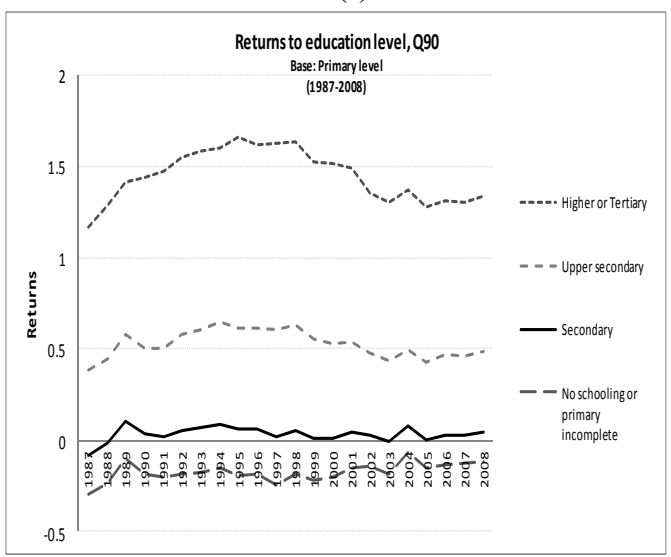


Figure 4. OLS and quantile regression coefficients to the marital status, gender and experience (1987-2008).

(a)

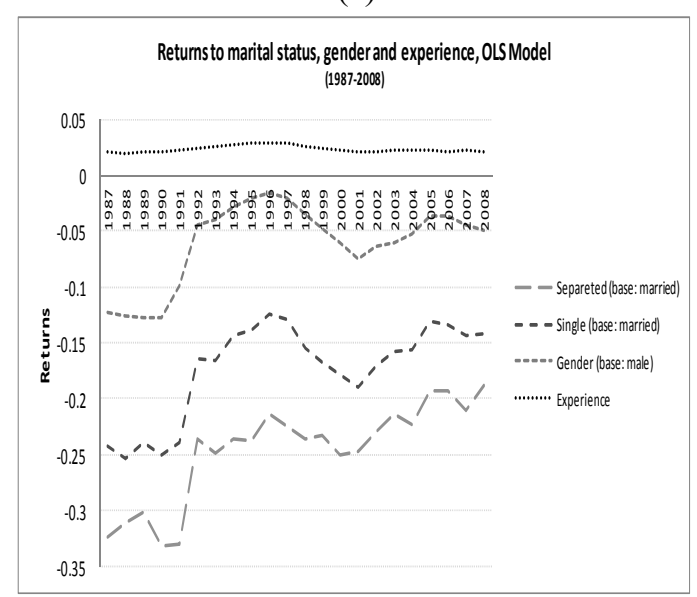

(c)

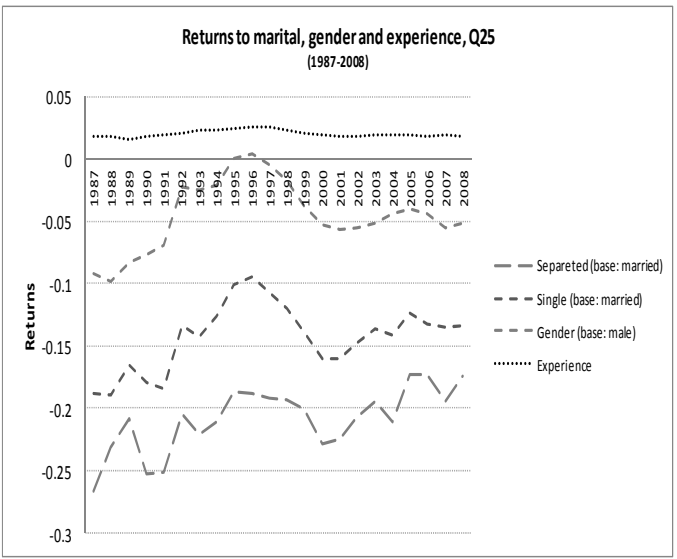

(e)

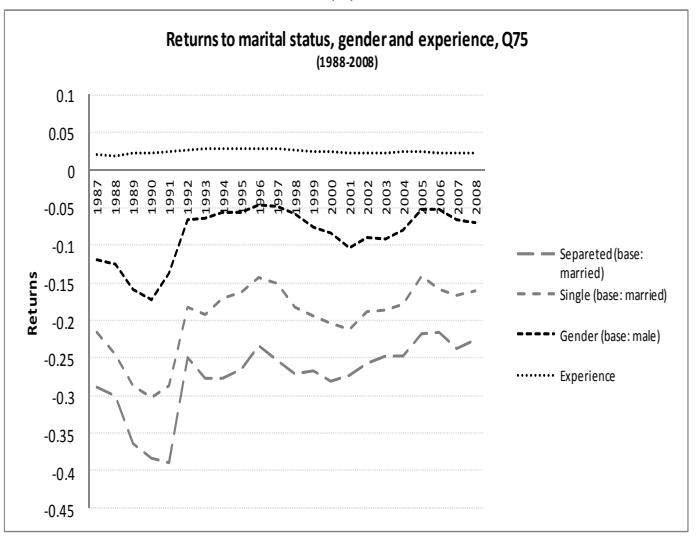

Source: Own elaboration from ENEU-ENOE 1987-2008. (b)

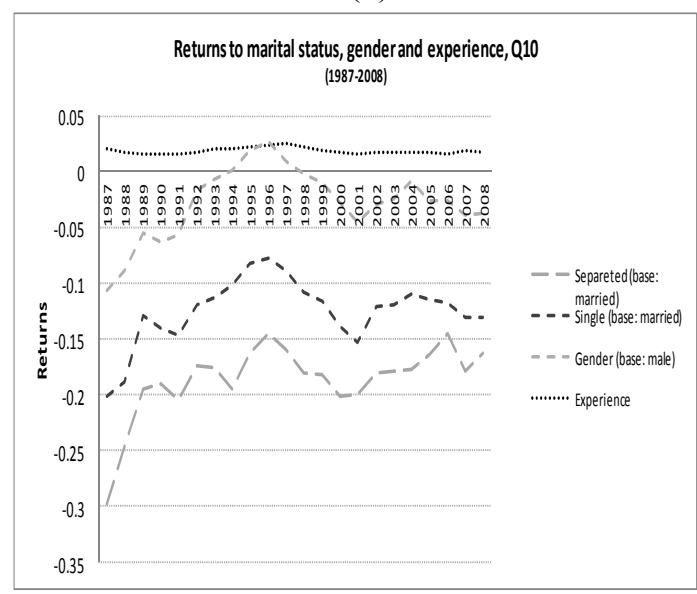

(d)

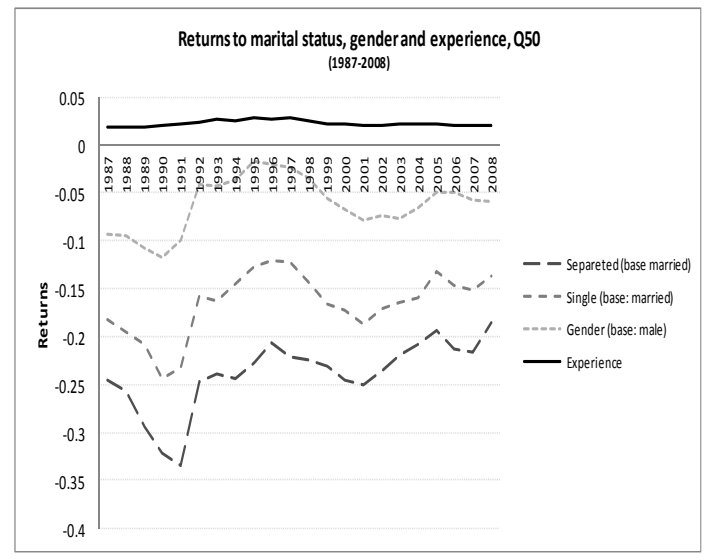

(f)

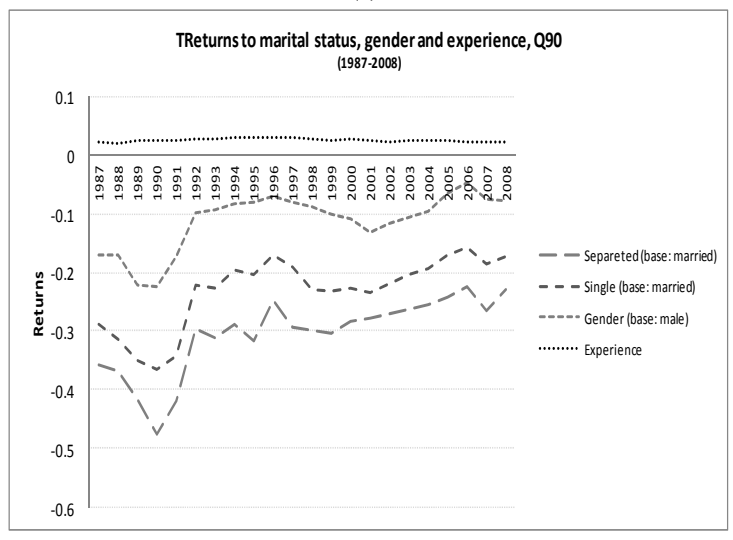


Figure 5. OLS and quantile regression coefficients to occupation (1987-2008).

(a)

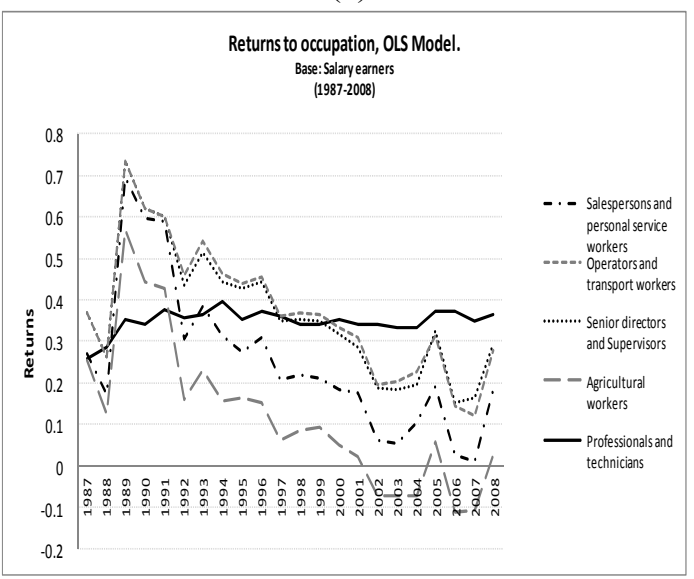

(c)

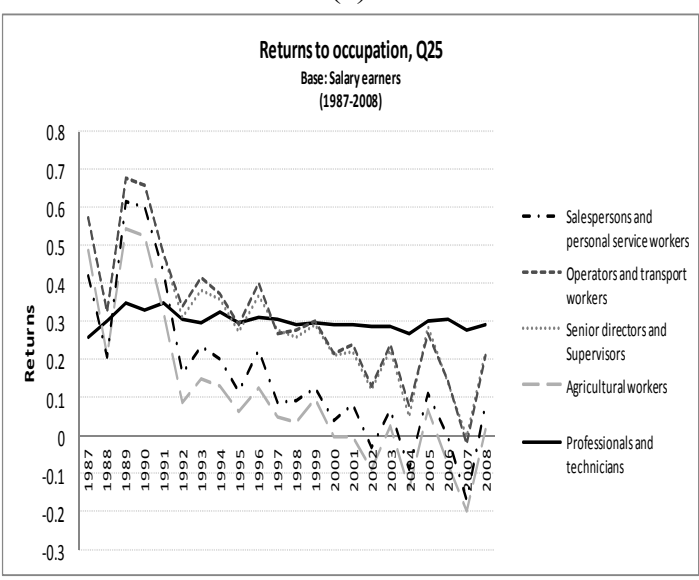

(e)

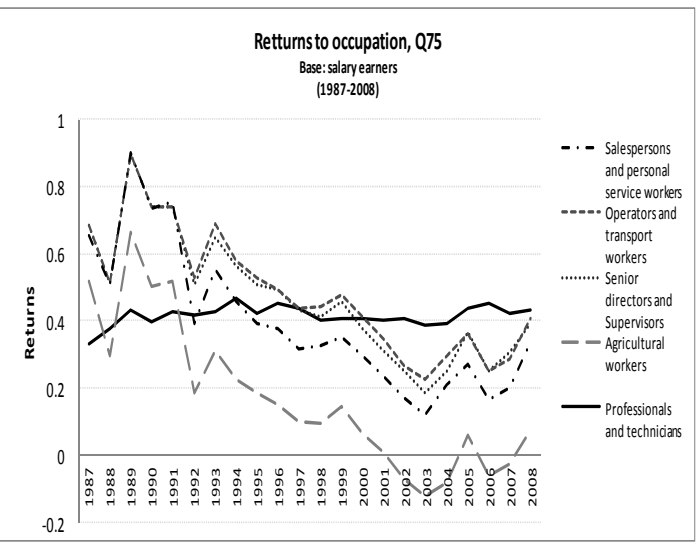

Source: Own elaboration from ENEU-ENOE 1987-2008. (b)

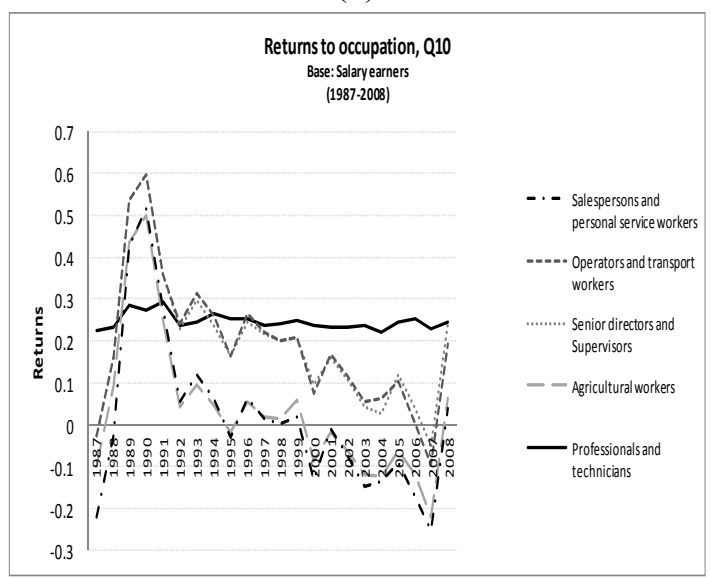

(d)

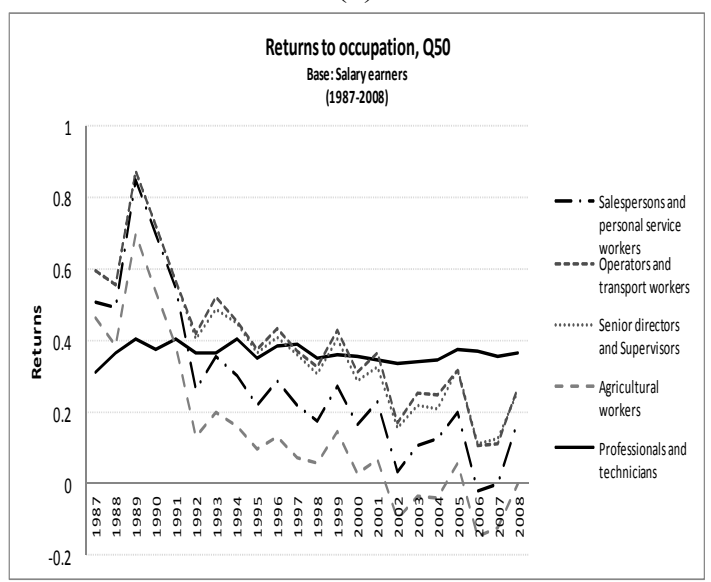

(f)

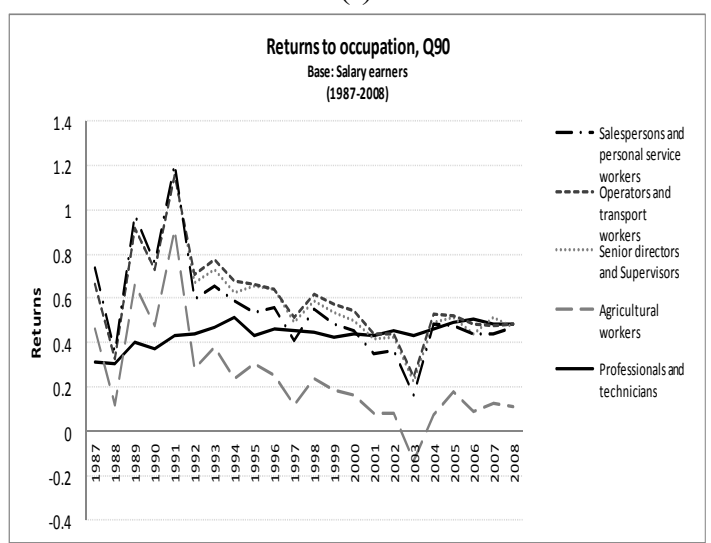


Figure 6. OLS and quantile regression coefficients to economic sector (1987-2008).

(a)

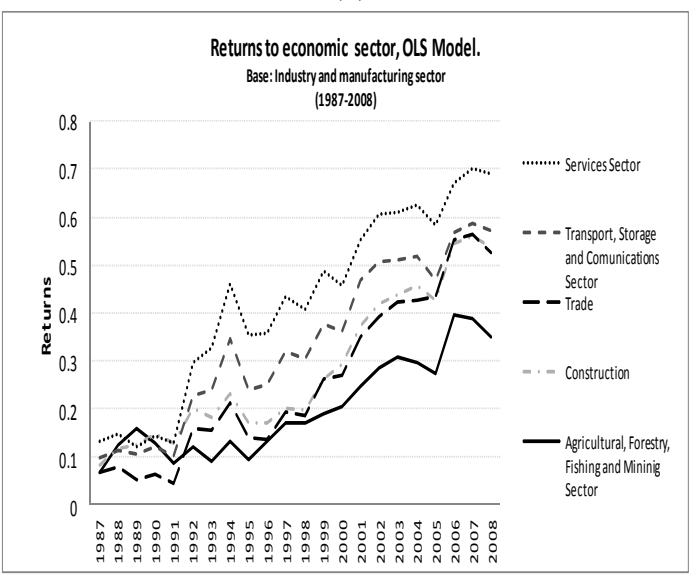

(c)

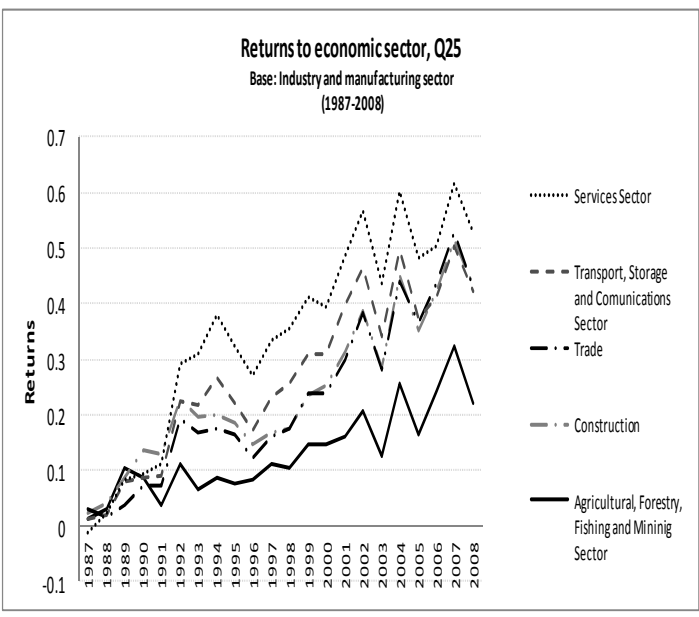

(e)

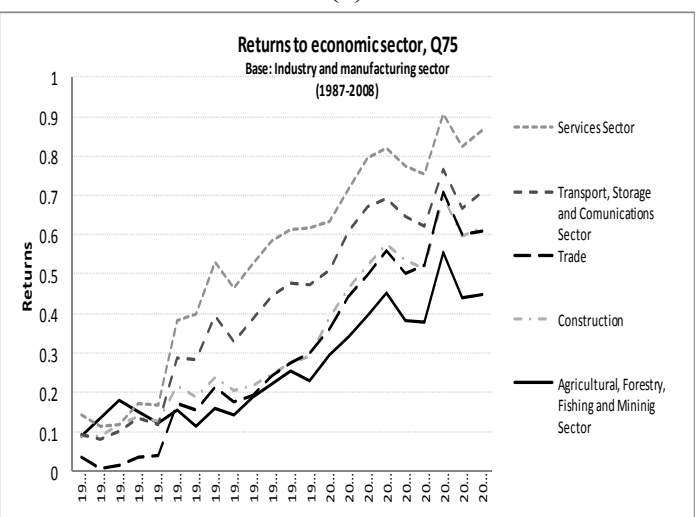

Source: Own elaboration from ENEU-ENOE 1987-2008. (b)

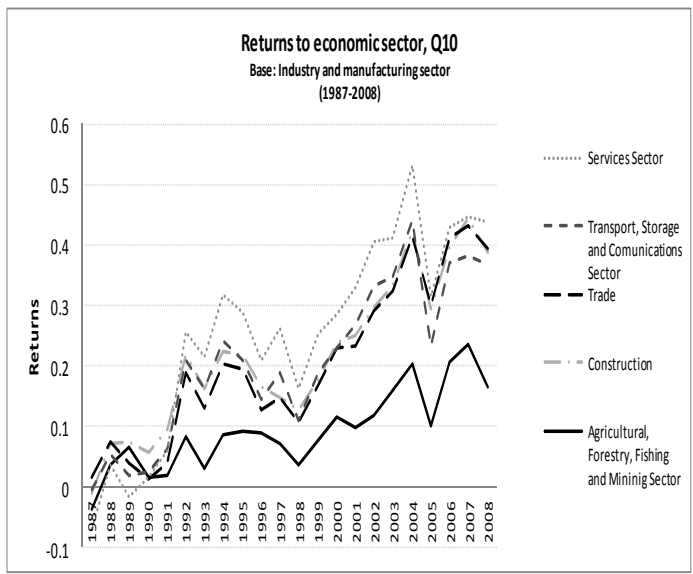

(d)

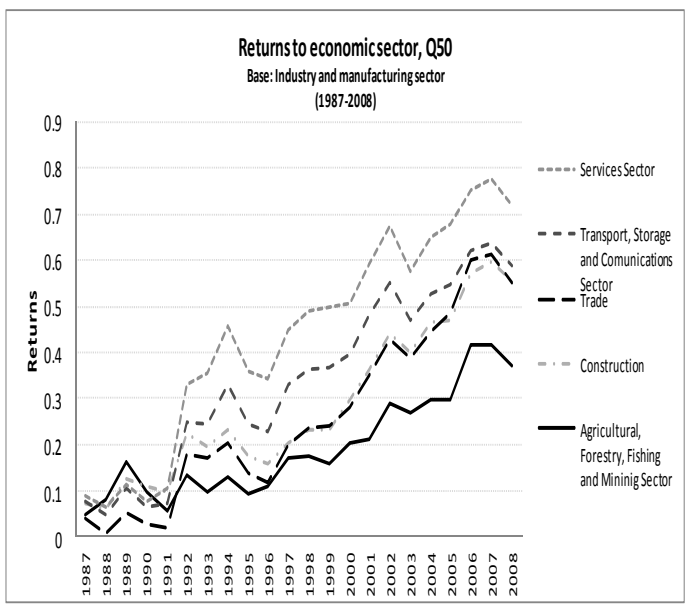

(f)

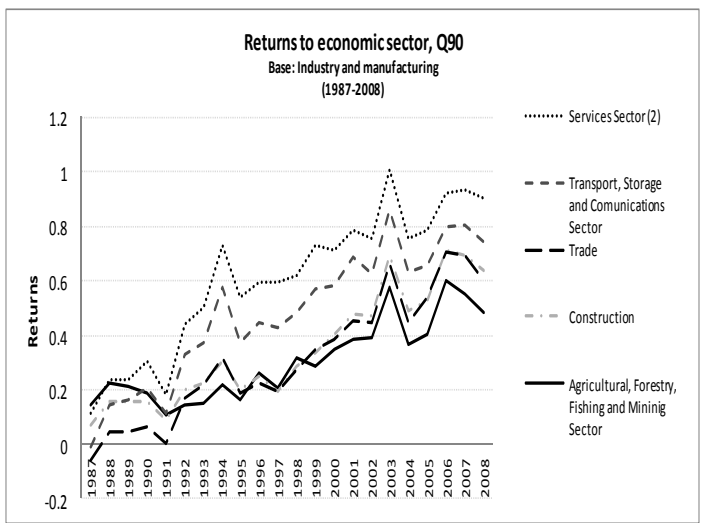


Figure 7. OLS and quantile regression coefficients to firm size (1987-2008).

(a)

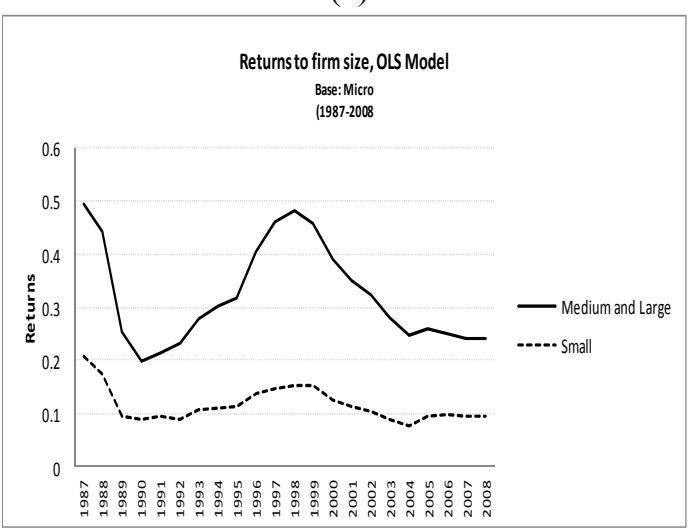

(c)

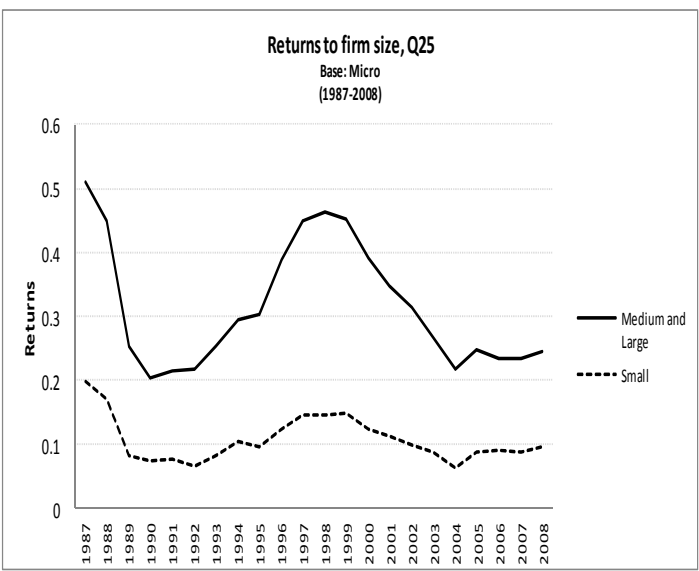

(e)

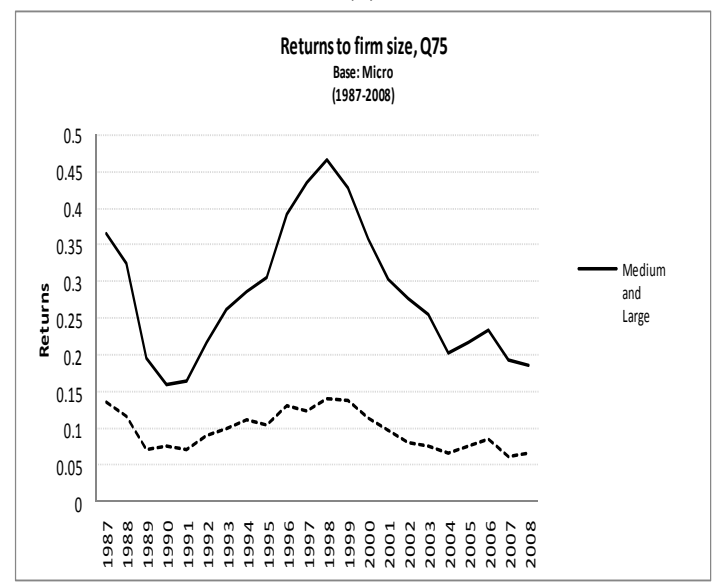

Source: Own elaboration from ENEU-ENOE 1987-2008. (b)

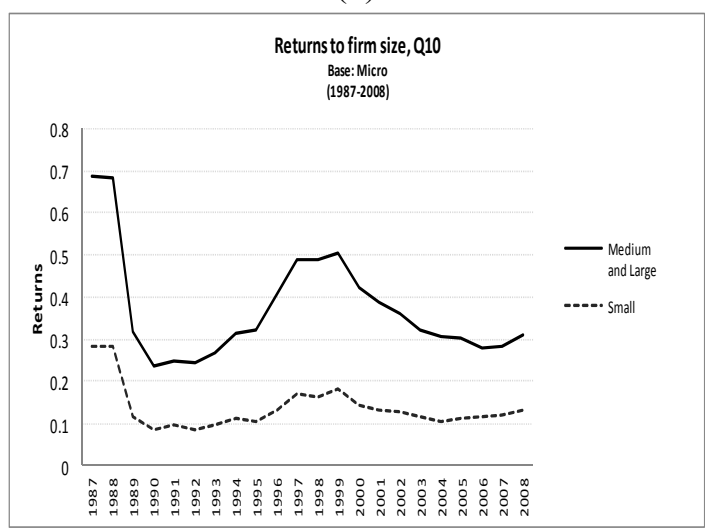

(d)

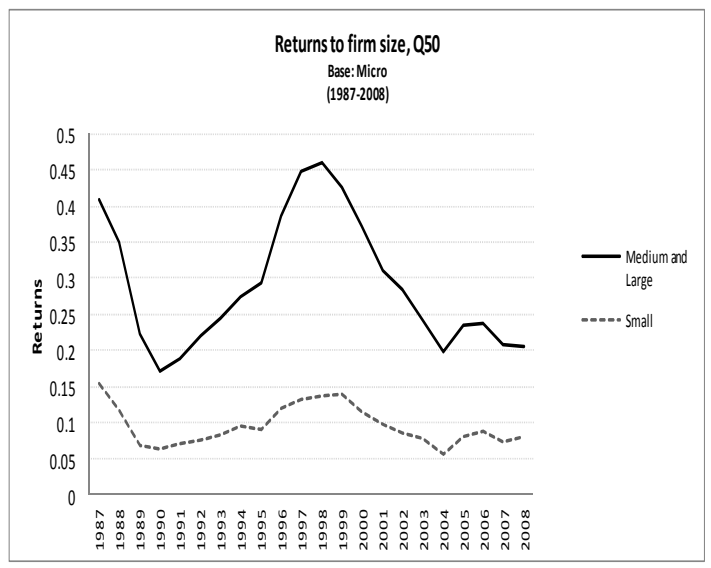

(f)

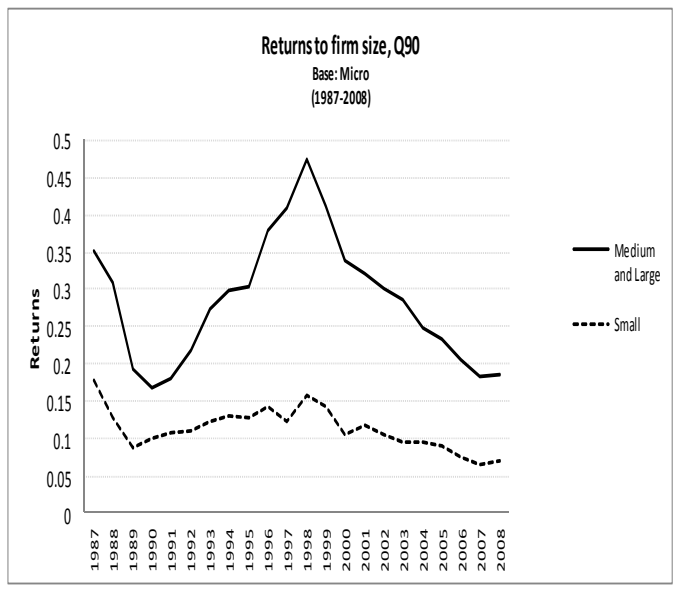


Table 4. Quantile and inequality decomposition in the contributions related to covariates, coefficients (between) and residuals

(within) in Mexico, 1987-2008.

\begin{tabular}{|c|c|c|c|c|c|c|c|c|c|c|c|c|c|c|c|c|}
\hline $1987-2008$ & 10th & $(\%)$ & 25th & $(\%)$ & Median & $(\%)$ & 75th & $(\%)$ & 90th & $(\%)$ & $90 / 10$ & $(\%)$ & $50 / 10$ & $(\%)$ & $90 / 50$ & $(\%)$ \\
\hline Total estimated variation & $\begin{array}{c}-0.066 \\
(0.0065)\end{array}$ & 1.0 & $\begin{array}{c}-0.040 \\
(0.0043)\end{array}$ & 1.0 & $\begin{array}{c}-0.202 \\
(0.0045)\end{array}$ & 1.0 & $\begin{array}{c}0.027 \\
(0.0063)\end{array}$ & 1.0 & $\begin{array}{c}0.397 \\
(0.0088)\end{array}$ & 1.0 & 0.463 & 1.0 & -0.136 & 1.0 & 0.599 & 1.0 \\
\hline Covariates contribution & $\begin{array}{c}0.148 \\
(0.0026)\end{array}$ & -2.2 & $\begin{array}{c}0.075 \\
(0.0024)\end{array}$ & -1.9 & $\begin{array}{c}-0.013 \\
(0.0028)\end{array}$ & 0.1 & $\begin{array}{c}-0.162 \\
(0.0041)\end{array}$ & -6.0 & $\begin{array}{c}-0.348 \\
(0.0053)\end{array}$ & -0.9 & -0.495 & -1.1 & -0.160 & 1.2 & -0.335 & -0.6 \\
\hline $\begin{array}{l}\text { Coefficients contribution } \\
\text { (between) }\end{array}$ & $\begin{array}{c}0.411 \\
(0.0050)\end{array}$ & -6.2 & $\begin{array}{c}0.161 \\
(0.0041)\end{array}$ & -4.0 & $\begin{array}{c}0.011 \\
(0.0041)\end{array}$ & -0.1 & $\begin{array}{c}-0.064 \\
(0.0052)\end{array}$ & -2.4 & $\begin{array}{c}-0.144 \\
(0.0079)\end{array}$ & -0.4 & -0.556 & -1.2 & -0.401 & 2.9 & -0.155 & -0.3 \\
\hline
\end{tabular}

Source: Authors' own calculations. Results based on data panel ENEU-ENOE surveys from 1987 to 2008

Note: the results have been multiplied by 100 . Bootstrap standard errors with 100 replications in parentheses.

Figure 8. Decomposition of differences in distribution using quantile regression (1987-2008)

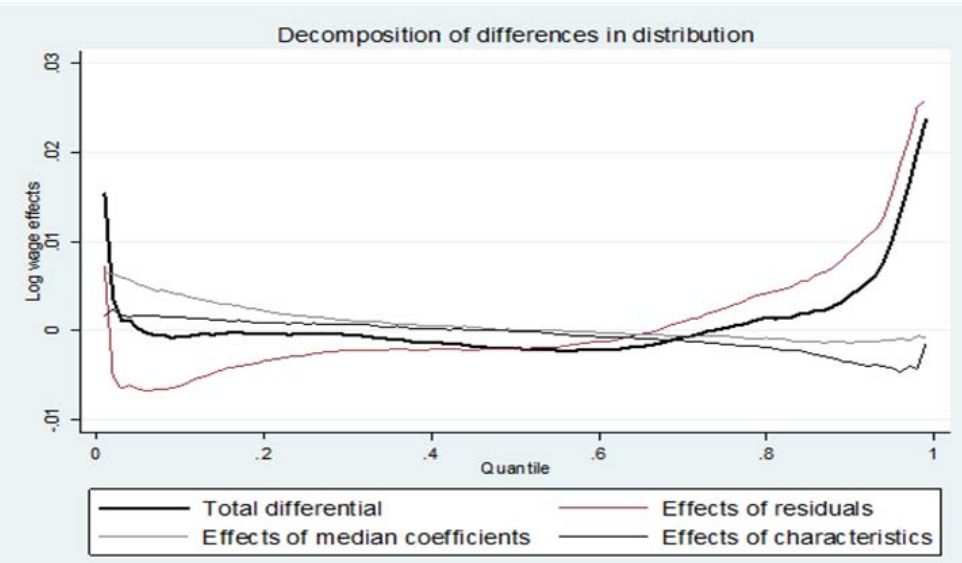

Source: Based on ENEU-ENOE 1987-2008.
Figure 9. Total Residual effects of decomposition in distribution using quantile regression (1987-2008)

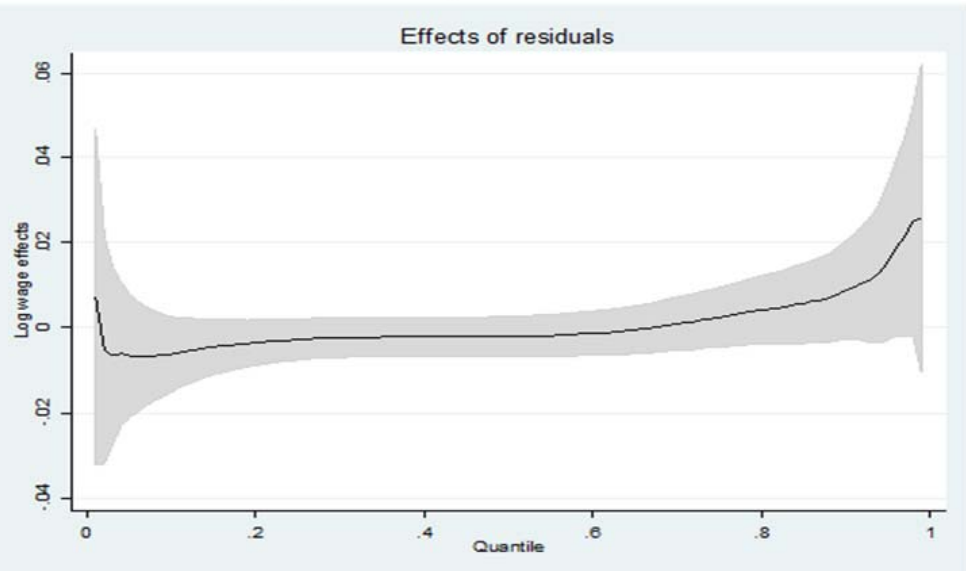

Source: Based on ENEU-ENOE 1987-2008. 


\section{$\underset{\Theta}{\mathbb{Q}}|\mathrm{R}| \mathrm{E}|\mathrm{A}|$}

Institut de Recerca en Economia Aplicada Regional i Públic

Research Institute of Applied Economics

WEBSITE: www.ub-irea.com • CONTACT: irea@ub.edu

\section{AQR}

Grup de Recerca Anàlisi Quantitativa Regional

Regional Quantitative Analysis Research Group

WEBSITE: www.ub.edu/aqr/·CONTACT: aqr@ub.edu

\section{Universitat de Barcelona}

